\title{
In situ protein degradation of alfalfa and birdsfoot trefoil hays and silages as influenced by condensed tannin concentration ${ }^{1}$
}

\author{
W. K. Coblentz ${ }^{* 2}$ and J. H. Grabbert \\ *US Department of Agriculture-Agricultural Research Service (USDA-ARS), US Dairy Forage Research Center, Marshfield, WI 54449 \\ † US Department of Agriculture-Agricultural Research Service (USDA-ARS), US Dairy Forage Research Center, Madison, WI 53706
}

\begin{abstract}
Dairy cattle often make poor use of protein when offered diets comprising high proportions of alfalfa (Medicago sativa L.) hay or silage because nonprotein $\mathrm{N}$ formed during forage conservation and ruminal fermentation exceeds requirements for rumen microbial protein synthesis; however, condensed tannins (CT) may reduce proteolysis in the silo and in the rumen, thereby potentially improving the efficiency of crude protein (CP) use in ruminant diets. Two harvests, yielding 12 hays and 12 silages made from alfalfa and birdsfoot trefoil (Lotus corniculatus L.) that varied in concentrations of CT, were evaluated for in situ disappearance kinetics of $\mathrm{CP}$ in 6 ruminally cannulated lactating Holstein dairy cows $(627 \pm 56.3 \mathrm{~kg})$. Prior to conservation, alfalfa contained no detectable $\mathrm{CT}$, whereas $\mathrm{CT}$ in fresh lyophilized birdsfoot trefoil ranged from 1.16 to $2.77 \%$ of dry matter, as determined by a modified acetone-butanol-HCl assay. Percentages of $\mathrm{CP}$ remaining at each incubation time were fitted to nonlinear regression models with or without a discrete lag time. Effective ruminal disappearance of $\mathrm{CP}$ (rumen-degradable protein, RDP) was calculated by 3 procedures that included (1) no discrete lag $\left(\mathrm{RDP}_{\mathrm{NL}}\right)$, (2) discrete lag $\left(\mathrm{RDP}_{\mathrm{L}}\right)$, and (3) discrete lag with a lag adjustment $\left(\mathrm{RDP}_{\mathrm{LADJ}}\right)$. Regardless of the calculation method, RDP declined linearly with increasing CT concentrations $\left(\mathrm{R}^{2}=0.62\right.$ to 0.97$)$. Generally, tests of homogeneity showed that conservation type (hay or silage) or harvest (silage only) affected intercepts, but not slopes in regressions of RDP on $\mathrm{CT}$. A positive relationship between lag time and CT suggests that the $\mathrm{RDP}_{\text {LADJ }}$ approach may be most appropriate for calculating RDP for legumes containing tannins. With this approach, regression intercepts were mainly affected by
\end{abstract}

\footnotetext{
Received August 29, 2012.

Accepted January 9, 2013.

${ }^{1}$ Mention of trade names or commercial products in this article is solely for the purpose of providing specific information, and does not imply either recommendation or endorsement by the US Department of Agriculture.

${ }^{2}$ Corresponding author: wayne.coblentz@ars.usda.gov
}

conservation method, and $\mathrm{RDP}_{\mathrm{LADJ}}$ averaged 77.5 and $88.7 \%$ of $\mathrm{CP}$ for hay and silage, respectively, when no $\mathrm{CT}$ was present. Greater estimates of RDP for silages were related to extensive proteolysis in laboratory silos resulting in conversions of protein into nonprotein $\mathrm{N}$ forms, which readily washed out of Dacron bags. When $\mathrm{RDP}_{\mathrm{LADJ}}$ and $\mathrm{CT}$ were expressed on a $\mathrm{CP}$ basis, regression slopes indicated that each unit of $\mathrm{CT}$ protected 0.61 units of CP from ruminal degradation in hays and silages. Applying this relationship to a typical mid-maturity forage legume containing $21 \% \mathrm{CP}$ suggests that a CT concentration of $3.8 \%$ of DM would be required to reduce RDP from $81 \%$ to a $70 \%$ target considered optimal for improving protein utilization and milk yields by dairy cattle.

Key words: condensed tannins, effective ruminal disappearance, in situ, protein

\section{INTRODUCTION}

Alfalfa (Medicago sativa L.) is commonly used as high-protein forage in diets of lactating cows. Typically, alfalfa is offered as either dry hay or silage, and only about $20 \%$ of the CP in alfalfa escapes the rumen intact. Degradation of alfalfa proteins may occur during silage fermentation (via proteolysis), or during ruminal fermentation after ingestion by dairy cows (Hoffman et al., 1993; Coblentz et al., 1998; NRC, 2001). Although NPN products of pregastric (primarily silage) proteolysis are converted to rumen microbial proteins of high nutritional value, excess NPN formed from alfalfabased diets is ultimately absorbed from the rumen as ammonia, detoxified by conversion to urea in the liver, and then excreted in the urine. Thus, excessive RDP in alfalfa not only reduces the efficiency of feed protein utilization, but also creates a metabolic burden that reduces dairy cow performance. Furthermore, ureases in manure readily convert excreted urea to ammonia, thereby contributing to atmospheric pollution from farms.

In response to these problems, various internal and external processes, such as plant maturity (Hoffman et al., 1993; Cassida et al., 2000), mechanical maceration 
at harvest (Grabber and Coblentz, 2009; Grabber et al., 2011), chemical treatments, modified atmospheres, or heating during conservation (Nagel and Broderick, 1992; Makoni et al., 1997; Coblentz et al., 2010), and protein protection by condensed tannins $(\mathbf{C T})$ or other polyphenols (Broderick and Albrecht, 1997; Grabber and Coblentz, 2009; Grabber et al., 2011) have been evaluated for reducing proteolysis of alfalfa during conservation and ruminal fermentation. Among these, naturally occurring CT in legume forages have been the most intensively studied, not only as a means for limiting RDP and improving protein utilization, but also for reducing bloat and parasitism in ruminants, as well as reducing the emission of ammonia and methane from livestock operations. The benefits and limitations of feeding CT-containing forage to ruminant livestock have been summarized in several review publications (Waghorn, 2008; Patra and Saxena, 2011). Due to the perceived benefits of CT, genetic engineering efforts are underway to express these polyphenolic compounds in herbage of alfalfa and other major forage legume species (Hancock et al., 2012; Verdier et al., 2012).

Although proteolysis is clearly limited by $\mathrm{CT}$, relationships between RDP and CT remain poorly defined for temperate forage legumes conserved as hay or silage. This is due to several factors, such as the widespread use of freeze-dried herbage rather than silage or hay to determine RDP by rumen microflora, or the use of surrogate RDP methods, such as protease assays, that have not been validated for CT-containing forages (Grabber, 2009; Grabber et al., 2011). Relationships between RDP and CT often have been determined by using multiple forage species, without regard to confounding caused by differences in CT chemistry, which is known to influence protein precipitation and proteolytic inhibition (Aerts et al., 1999; McAllister et al., 2005). Forages used in such studies also have varied in concentrations of $\mathrm{CP}$ and fiber constituents, thereby affecting RDP by changing the proportions of readily degraded cell-soluble $\mathrm{CP}$ and slowly degraded fiber-associated CP in herbage (Coblentz et al., 1998; Cassida et al., 2000). Difficulties in accurately estimating CT concentrations also hamper work to assess their effects on RDP estimates. The butanol- $\mathrm{HCl}$ assay is widely considered to be among the most accurate and convenient methods for quantifying CT, but standards must be isolated from the forage of interest (Schofield et al., 2001). However, work by Makkar et al. (1999) also suggests that incomplete hydrolysis of CT can lead to an underestimation of $\mathrm{CT}$ concentrations in plant tissues. More recent work suggests that CT fractions prepared by commonly used extraction and columnchromatography methods can be highly contaminated with non-CT components [W. E. Zeller, US Depart- ment of Agriculture-Agricultural Research Service (USDA-ARS), US Dairy Forage Research Center, Madison, WI, and I. Mueller Harvey, University of Reading, Reading, UK, personal communication]. This previously overlooked problem will lead to an overestimation of $\mathrm{CT}$ concentrations by the butanol- $\mathrm{HCl}$ assay unless the purity of such standards is determined.

Therefore, we sought to minimize these collective confounding effects in this study by selecting hays and silages from 2 harvests of alfalfa and birdsfoot trefoil (BFT) that were similar with respect to concentrations of $\mathrm{CP}$ and NDF, but differed in $\mathrm{CT}$, to determine ruminal degradation characteristics of CP. Ruminal degradation characteristics were then related to $\mathrm{CT}$ concentration, which was determined with improved accuracy by a modified butanol- $\mathrm{HCl}$ assay conducted with acetone as a co-solvent and using a BFT standard of defined chemical purity. We selected BFT as the CT-containing forage for this study because its maturation, morphology, and protein and fiber characteristics are comparable with those of alfalfa (Buxton et al., 1985; Cassida et al., 2000) and the properties of its CT appear especially desirable for enhancing protein utilization by ruminants, at least when fresh forage is consumed (Waghorn, 2008; Patra and Saxena, 2011). The ultimate objective of this approach was to define optimal concentrations and types of CT required in legume hays and silages for limiting pregastric proteolysis while increasing protein flow to the small intestine in dairy cattle and other ruminants.

\section{MATERIALS AND METHODS}

\section{Forages}

Selection of Forages. Initially, a large set of 0.9 $\times$ 6.0-m replicated plots comprised of 1 alfalfa and 11 BFT cultivars were established during 2005 on a silt loam soil on the US Dairy Forage Research Center Farm, located near Prairie du Sac, Wisconsin. Two field replicates of each cultivar were harvested from June 5 to 7 (HRVST 1), and from July 9 to 11, 2007 (HRVST 2), which represented initial spring growth and first regrowth, respectively. Overall, the $11 \mathrm{BFT}$ cultivars exhibited a diverse range of concentrations of $\mathrm{CT}$, which was an integral component of the final selection criteria for in situ analysis. Other selection criteria included a desire to maintain relative uniformity with respect to concentrations of NDF and $\mathrm{CP}$ across all alfalfa and BFT forages. Consequently, forage from single plots of 5 BFT cultivars (Dewey, Goldie, Lotanova, Georgia, and Exact) and 1 alfalfa cultivar (Spredor 4) that most closely met these criteria were selected for subsequent in situ analysis. Each cultivar 
$\times$ harvest date combination was conserved as both hay $(\mathbf{H Y})$ and silage (SLG), thereby yielding a factorial arrangement of 6 (cultivar) $\times 2$ (harvest date) $\times 2$ (conservation method) treatments.

Harvest and Conservation. Plots were cut near midday with a sickle-bar mower to a 5-cm stubble height and weeds were quickly removed by hand. A subsample of herbage was then frozen on dry ice, lyophilized, and ground through a 1-mm screen in a cyclone mill (Udy Corp., Fort Collins, CO) pending subsequent laboratory analysis of CT. A 6.6-kg sample of fresh herbage from each plot was distributed equally across 2 plastic screens with 1-mm openings at a density of $5 \mathrm{~kg} / \mathrm{m}^{2}$. Screens were placed in forced-air ovens operated at a reduced drying temperature $\left(35^{\circ} \mathrm{C}\right)$ for $3 \mathrm{~h}$, and then stored overnight in an adjacent shelter at an ambient temperature that decreased during the night from approximately 25 to $15^{\circ} \mathrm{C}$. Screens containing these forages were returned to the dryer the following morning, and dehydration was continued at $35^{\circ} \mathrm{C}$. These procedures were adopted to simulate the cyclic, diurnal nature of ambient summer temperatures, improve the uniformity of drying within and between harvests, preclude rain damage to the forage, and minimize leaf loss, particularly from HY during wilting. When the DM concentration of the forages reached 40\% (approximately 24 $\mathrm{h}$ after mowing), the forage on 1 screen per plot was coarsely chopped, and then vacuum ensiled in $20 \times 40$ $\mathrm{cm}$ double-lined plastic bags, thereby establishing the SLG conservation treatment. Silage fermentation was allowed to continue for $60 \mathrm{~d}$ at $25^{\circ} \mathrm{C}$, and then silages were removed from plastic silo bags, subsampled for pH (Owens et al., 1999), frozen on dry ice, and lyophilized. Herbage on the other mesh screen remained in the dryer continuously at $35^{\circ} \mathrm{C}$ until the concentration of DM exceeded $90 \%$, thereby simulating conservation as HY. Any effects of curing or sweating after baling for HY were not considered with these procedures. All dried SLG and HY samples were then ground through either a 1-mm screen in the Udy cyclone mill (described previously) or a 2 -mm screen in a Thomas model 4 Wiley mill (Thomas Scientific, Swedesboro, NJ). Portions of each sample ground through the cyclone mill were retained in sealed plastic vials at room temperature pending laboratory analysis for fiber components (NDF, ADF, hemicellulose, and ADL) and CP. Subsamples ground through the 2-mm screen in a Wiley mill were retained for in situ analysis of ruminal $\mathrm{CP}$ disappearance.

\section{Sample Analysis}

$\boldsymbol{C T}$. To estimate the concentrations of total CT in fresh herbage, lyophilized samples $(30 \mathrm{mg})$ and CT standards $(0.1$ to $1.0 \mathrm{mg})$ were heated in sealed tubes at $70^{\circ} \mathrm{C}$ for $2.5 \mathrm{~h}$ with $15 \mathrm{~mL}$ of acetone-butanol- $\mathrm{HCl}$ reagent, which was prepared with $400 \mathrm{mg}$ of ammonium iron (III) sulfate dodecahydrate/L, $33 \mathrm{~mL}$ of water/L, $50 \mathrm{~mL}$ of $12 \mathrm{M} \mathrm{HCl} / \mathrm{L}$, and $500 \mathrm{~mL}$ of acetone/L and brought to volume with butanol. After cooling, a subsample of hydrolysate was centrifuged for 2 min at $10,000 \times g$, and read on a spectrophotometer at $554 \mathrm{~nm}$, using the butanol- $\mathrm{HCl}$ reagent as a blank. A CT standard from BFT was generously provided by I. Mueller-Harvey (University of Reading, UK), having a mean degree of polymerization of 30 and a purity of $99 \%$ as determined by thiolysis. This analytical process also indicated that the standard was composed of a 60:40 ratio of procyanidin to prodelphinidin units, which is typical of CT isolated from BFT (Sivakumaran et al., 2006). Heated butanol-HCl hydrolysates of alfalfa, which lacked a proanthocyanidin absorption peak, were used to adjust absorption values for co-extracted pigments; this reduced CT concentrations in BFT by an average of 0.1 percentage units.

Nutritive Value. Laboratory DM concentrations for all dried, ground HY, and SLG samples were determined by oven drying at $105^{\circ} \mathrm{C}$ for $24 \mathrm{~h}$. Analyses of forage fiber components were conducted sequentially without sodium sulfite or amylase using batch procedures outlined by Ankom Technology Corp. (Macedon, $\mathrm{NY}$ ) for an $\mathrm{ANKOM}^{200}$ fiber analyzer. Concentrations of $\mathrm{N}$ in all samples were determined by a combustion procedure (AOAC International, 1998; method 990.03; model FP2000 combustion analyzer; Leco Corp., St Joseph, MI), and CP was calculated as $\mathrm{N} \times 6.25$.

\section{In Situ Analysis}

Diet and Animals. For this study, cannulations (protocol no. A-1307) and care of the cows (protocol no. A-1339) were approved by the Research Animal Resources Center of the University of WisconsinMadison. Six late-lactation $(627 \pm 56.3-\mathrm{kg} ; 256 \pm 4.8$ DIM) ruminally cannulated Holstein cows were housed in individual tiestalls at the US Dairy Forage Research Center Farm (Prairie du Sac, WI), and offered a basal diet consisting of (DM basis) 29.1\% corn silage, $27.9 \%$ alfalfa haylage, $24.9 \%$ high-moisture corn, $7.4 \%$ roasted soybeans, $3.7 \%$ fuzzy cottonseed, $1.2 \%$ soybean meal, $1.9 \%$ dried distillers grains, $1.5 \%$ blood meal, with the balance added as a commercial mineral mix (composition: $0.5 \mathrm{~g}$ of monensin $/ \mathrm{kg}, 14.7$ to $16.7 \% \mathrm{Ca}, 10.0$ to $12.0 \%$ salt, 13.8 to $15.8 \% \mathrm{Na}, 4.3 \% \mathrm{Mg}, 0.9 \% \mathrm{~S}, 14.2$ $\mathrm{mg}$ of $\mathrm{Se} / \mathrm{kg}, 284,225 \mathrm{IU}$ of vitamin $\mathrm{A} / \mathrm{kg}, 56,845 \mathrm{IU}$ of vitamin $\mathrm{D}_{3} / \mathrm{kg}$, and $1,336 \mathrm{IU}$ of vitamin $\mathrm{E} / \mathrm{kg}$; Vita Plus Corp., Madison WI). The DM concentration of the complete blended diet was $46.3 \%$, and its nutri- 
tional composition was $16.6 \% \mathrm{CP}, 27.2 \% \mathrm{NDF}, 5.1 \%$ fat, $0.89 \% \mathrm{Ca}, 0.31 \% \mathrm{P}$, and $71.2 \% \mathrm{TDN}$, and $\mathrm{NE}_{\mathrm{L}}=$ $1.63 \mathrm{Mcal} / \mathrm{kg}$ (University of Wisconsin Soil and Forage Laboratory, Marshfield, WI). This was the normal production diet offered to these cows before the trial was initiated, as well as to all other nontrial cows at this stage of lactation. Under these circumstances, there was no need to adapt cows to the composition of the basal diet; however, a common daily offering (2.93\% of BW) was established. This was determined beginning approximately 2 wk before the trial was initiated, and was based on the daily monitored intakes of the 6 cannulated cows. The threshold of $2.93 \%$ of BW represented the minimum intake exhibited by any of the 6 cows during this preliminary evaluation period. All cows were then adjusted to this common daily rate for $7 \mathrm{~d}$ before beginning in situ analysis.

In reviewing in situ procedures for the specific purpose of standardizing methodology, Vanzant et al. (1998) recommended a maintenance level of intake across all experimental animals, in part because ad libitum intakes are incompatible with standardization of techniques. This is especially important when DMI affects the ruminal disappearance of the forages or feedstuffs to be evaluated. For this experiment, there was no a priori knowledge of potential effects of DMI on ruminal disappearance of CP from our 24 test forages. However, we theorized that establishing a common level of DMI (\% of BW basis) across all cows would negate any potential confounding of results by eliminating cow-tocow differences in ad libitum DMI. Furthermore, because the final application of these results was specific to lactating dairy cows, we felt it important to evaluate these forages in mid-to-late-lactation cows consuming a typical (basal) production diet appropriate for cows at that stage of lactation.

In Situ Procedures. Five-grams of each dried, ground (2-mm screen) HY and SLG were sealed in 10 $\times 20$-cm Dacron bags (50 $\pm 10-\mu \mathrm{m}$ pore size; Ankom Technology, Corp.). Subsequently, Dacron bags were sorted by cow and withdrawal time, secured in $35 \times 50$ $\mathrm{cm}$ mesh bags, soaked in tepid water $\left(39^{\circ} \mathrm{C}\right)$ for $20 \mathrm{~min}$, and then immediately suspended in the ventral rumen for $3,6,12,18,24,48$, or $96 \mathrm{~h}$. All bags were inserted into the rumen simultaneously. Dacron bags designated for a 12-h incubation period were evaluated in triplicate for an independent research project; therefore, for the current study, these observations simply were averaged, and their mean was used for the 12-h withdrawal time in all subsequent calculations. After removal from the rumen, Dacron bags were washed immediately in cold water in a top-loading washing machine (10 total rinse cycles, 1 min agitation and 2 min spin per rinse; Coblentz et al., 1997; Vanzant et al., 1998). Six addi- tional Dacron bags containing each HY and SLG were preincubated and rinsed in the washer as described previously without ruminal incubation, thereby creating a 0 - $h$ incubation time. After machine rinsing, in situ residues were dried at $50^{\circ} \mathrm{C}$, and then equilibrated with the atmosphere in the laboratory before quantifying residual DM (Vanzant et al., 1996). To determine disappearance kinetics of $\mathrm{CP}$, the concentration of $\mathrm{CP}$ in each air-equilibrated residue was determined by the identical rapid combustion procedure described previously (AOAC International, 1998; method 990.03).

Curve-Fitting and Calculation of RDP. Ruminal degradation kinetics were calculated by 3 protocols: no lag (NL), lag (L), and lag adjustment (LADJ). Primarily, these methods of calculation were used to detect obvious effects of discrete lag time on the relationship between RDP and CT. For the NL method, percentages of $\mathrm{CP}$ remaining at each incubation time were fitted to the nonlinear regression model of Mertens and Loften (1980) using PROC NLIN of SAS (SAS Institute, 2002); however, a discrete lag time was omitted from the model, which implies that lag time $=0 \mathrm{~h}$ for all forages. This model partitioned CP into 3 fractions based on relative susceptibility to ruminal disappearance. Fractions $\mathbf{A}$ and $\mathbf{B}$ were defined as the proportions of $\mathrm{CP}$ disappearing at rates too fast to measure, or at a measurable rate, respectively. Fraction $\mathbf{C}$ was defined as that fraction of $\mathrm{CP}$ that was unavailable in the rumen. Fractions B and C, as well as ruminal degradation rate $\left(\mathbf{K}_{\mathbf{d}}\right)$ were estimated directly from the nonlinear regression model, and fraction $\mathrm{A}$ was calculated as 100\% - (B + C). Concentrations of RDP with $\mathrm{NL}\left(\mathbf{R D P}_{\mathrm{NL}}\right)$ were then calculated as $\mathrm{A}+\mathrm{B} \times\left[\mathrm{K}_{\mathrm{d}} /\right.$ $\left(\mathrm{K}_{\mathrm{d}}+\mathrm{Kp}\right)$ ] (Ørskov and McDonald, 1979), where Kp $=$ particulate passage rate that was set arbitrarily at $0.06 / \mathrm{h}$ to have relevance to passage kinetics in lactating dairy cows.

Calculations for the L method were essentially identical to those for NL, except that a discrete lag time was added to the ruminal disappearance model (Mertens and Loften, 1980). Concentrations of RDP for the $\mathrm{L}$ method $\left(\mathbf{R D P}_{\mathbf{L}}\right)$ were calculated as described previously, where $\mathrm{RDP}_{\mathrm{L}}=\mathrm{A}+\mathrm{B} \times$ $\left[\mathrm{K}_{\mathrm{d}} /\left(\mathrm{K}_{\mathrm{d}}+\mathrm{Kp}\right)\right]$ (Ørskov and McDonald, 1979). The Kp was again assumed to be $0.06 / \mathrm{h}$. For the LADJ method, estimates of fractions $\mathrm{A}, \mathrm{B}$, and $\mathrm{C} ; \mathrm{K}_{\mathrm{d}}$; and lag time were identical to those estimated under L procedures. However, once these ruminal disappearance characteristics were estimated, subsequent calculation of $\mathrm{RDP}_{\mathrm{L}}$ was adjusted to further consider the specific effects of discrete lag time $\left(\mathbf{R D P}_{\mathrm{LADJ}}\right)$, where $\mathrm{RDP}_{\mathrm{LADJ}}=\mathrm{A}+\mathrm{B} \times\left[\mathrm{K}_{\mathrm{d}} /\left(\mathrm{K}_{\mathrm{d}}+\mathrm{Kp}\right)\right] \times\left(\mathrm{e}^{-\left(\mathrm{K}_{\mathrm{d}}+\mathrm{Kp}\right) \times \mathrm{lag}}\right)$ (McDonald, 1981). 
Several reasons exist for including 3 approaches (NL, $\mathrm{L}$, and LADJ) for estimating RDP throughout this project. First, all 3 approaches have been used routinely (Hoffman et al., 1993; Rioux et al., 1995; Vanzant et al., 1996). Second, no real consensus exists concerning the inclusion or omission of a discrete lag time from ruminal disappearance models for CP. Broderick (1994) has suggested omission of a lag time from most models describing ruminal protein degradation; however, work with perennial warm-season grasses has suggested that discrete lag times can be much longer than those typically observed for dairy-quality forages (Coblentz et al., 1998; Ogden et al., 2006). Tabular summaries of RDP obtained from a wide range of forages and other feedstuffs compiled by NRC (2001) indicate that some contributing authors included a discrete lag in their model-fitting procedures, but no mention of the LADJ suggested by McDonald (1981) is included in discussions of kinetic calculations. Lastly, McDonald (1981) has stated that the simpler (and more commonly used) kinetic expression $\mathrm{RDP}=\mathrm{A}+\mathrm{B} \times\left[\mathrm{K}_{\mathrm{d}} /\left(\mathrm{K}_{\mathrm{d}}+\mathrm{Kp}\right)\right]$ is appropriate when there is no lag time, and probably gives acceptable estimates of RDP when the computed lag time is $<2 \mathrm{~h}$. Determinations of RDP for most dairy-quality legumes would fall within these guidelines. However, the specific effects of CT on estimates of RDP remain unclear, and potential exists for extending lag times beyond a 2-h threshold. For these reasons, all 3 approaches (NL, L, and LADJ) are reported and discussed to most clearly illustrate the effects of CT on estimates of RDP from dairy-quality legumes.

Before calculating disappearance kinetics by any of the described methods, a subset $(\mathrm{n}=48)$ of in situ residues selected with representation from all cows, forages, and incubation periods of $3,6,12,18,24$, and 48 $\mathrm{h}$ were analyzed for concentrations of purines by the methods of Zinn and Owens (1986) to assess levels of microbial contamination. The $96-\mathrm{h}$ incubation time was omitted because of limited residue following ruminal incubations. Purine concentrations for in situ residues were found to be negligible (overall mean $=1.8 \pm 0.80$ $\mathrm{mg} / \mathrm{g}$ ), and no corrections for microbial contaminant $\mathrm{N}$ were made before calculating kinetics of ruminal $\mathrm{CP}$ disappearance.

\section{Statistical Analysis}

The linear relationships between ruminal disappearance characteristics and concentrations of $\mathrm{CT}$ were tested for homogeneity of slopes and intercepts across conservation methods (HY or SLG) using PROC GLM of SAS (SAS Institute, 2002). If slopes, intercepts, or both differed $(P \leq 0.05)$ across conservation types, data were then resorted and reanalyzed by conservation type. In these cases, further testing of harvest date effects were conducted similarly; if responses for HRVST 1 and HRVST 2 were heterogeneous $(P \leq 0.05)$ within either conservation type for slope, intercept, or both, data were further sorted by harvest date, and linear regression equations were calculated with PROC REG of SAS (SAS Institute, 2002). In contrast, if these effects of harvest date produced homogeneous $(P>0.05)$ linear regression equations, data for HRVST 1 and HRVST 2 were pooled together before calculating the linear regression response on CT. All regressions of ruminal degradation characteristics on CT were based on concentrations of CT determined on lyophilized fresh forage sampled before the application of HY or SLG conservation treatments.

\section{RESULTS AND DISCUSSION}

\section{Forages}

Previous studies suggest RDP is influenced by the relative proportions of readily degraded cell-soluble $\mathrm{CP}$ and slowly degraded fiber-associated $\mathrm{CP}$ in alfalfa and BFT (Cassida et al., 2000; Coblentz et al., 2008). Therefore, a specific goal for selection of experimental forages was to maintain relatively narrow ranges with respect to concentrations of NDF and CP (Table 1) to minimize their effect on regression relationships between RDP and CT. The 24 conserved forages selected for in situ incubation exhibited minimal variation in these constituents, with NDF averaging (mean \pm SD) $39.3 \pm$ $1.49 \%$ and CP averaging $19.6 \pm 0.88 \%$. Concentrations of CT (Table 1) in fresh lyophilized herbage of the selected BFT cultivars ranged from 1.16 to $2.43 \%$ of DM in HRVST 1 and from 1.23 to $2.77 \%$ of DM in HRVST 2. As expected, no CT were detected in alfalfa from either harvest. Fresh lyophilized herbage is preferred for CT analysis because CT levels are more difficult to quantify after forage is conserved as hay, or especially as silage (Terrill et al., 1990; Minnee et al., 2002/2003). Our use of drying screens to largely eliminate leaf loss during wilting also helped to ensure that CT measured in fresh lyophilized herbage reflected the CT content of herbage conserved as SLG or HY. Across all forages, concentrations of $\mathrm{CT}$ were not correlated with $\mathrm{CP}(\mathrm{r}=$ $-0.21 ; P=0.32$ ), but a mild negative correlation was observed with $\mathrm{NDF}(\mathrm{r}=-0.45 ; P=0.026)$. For this study, the 12 forages conserved as SLG exhibited an appropriate DM (mean \pm SD) for silage fermentation $(40.2 \pm 3.3 \%)$, and they were properly fermented with a mean final $\mathrm{pH}$ of $4.23 \pm 0.122$.

\section{Evaluation of In Situ Kinetics}

Fraction A. Ruminal in situ degradation characteristics estimated with a discrete lag time by the $\mathrm{L}$ 
Table 1. Characteristics of nutritive value (expressed as \% of DM) of 6 legumes conserved as either wilted hay or silage following 2 independent harvests at Prairie du Sac, Wisconsin

\begin{tabular}{|c|c|c|c|c|c|c|c|}
\hline Cultivar & Conservation & $\mathrm{NDF}$ & $\mathrm{ADF}$ & HEMI $^{1}$ & Lignin & $\mathrm{CP}$ & $\mathrm{CT}^{2,3}$ \\
\hline \multicolumn{8}{|l|}{ Harvest 1} \\
\hline Dewey & Hay & 37.4 & 30.7 & 6.7 & 8.9 & 19.1 & 2.43 \\
\hline Goldie & Hay & 38.7 & 32.1 & 6.6 & 9.0 & 18.2 & 2.25 \\
\hline Georgia & Hay & 37.6 & 31.4 & 6.2 & 8.7 & 19.2 & 1.47 \\
\hline Exact & Hay & 38.6 & 32.2 & 6.4 & 8.4 & 19.6 & 1.16 \\
\hline Spredor ${ }^{4}$ & Hay & 41.3 & 34.7 & 6.6 & 8.1 & 19.4 & 0.00 \\
\hline Lotanova & Silage & 38.1 & 31.7 & 6.4 & 9.3 & 20.9 & - \\
\hline Georgia & Silage & 42.1 & 35.7 & 6.4 & 9.7 & 18.7 & - \\
\hline Exact & Silage & 41.5 & 33.4 & 8.1 & 9.3 & 19.8 & - \\
\hline Spredor $^{4}$ & Silage & 42.7 & 35.4 & 7.4 & 8.3 & 19.0 & - \\
\hline \multicolumn{8}{|l|}{ Harvest 2} \\
\hline Dewey & Hay & 40.1 & 33.6 & 6.5 & 9.7 & 18.0 & 2.77 \\
\hline Goldie & Hay & 38.8 & 32.0 & 6.8 & 9.4 & 20.0 & 2.51 \\
\hline Goldie & Silage & 38.5 & 33.0 & 5.5 & 10.0 & 20.5 & - \\
\hline Lotanova & Silage & 39.0 & 33.0 & 6.0 & 9.9 & 20.2 & - \\
\hline Georgia & Silage & 40.5 & 33.6 & 6.9 & 9.7 & 20.2 & - \\
\hline & Silage & 39.3 & 33.2 & 6.1 & 9.7 & 21.4 & - \\
\hline \multirow{3}{*}{ Spredor ${ }^{4}$} & Silage & 40.9 & 33.8 & 7.1 & 8.2 & 20.3 & - \\
\hline & Mean $^{5}$ & 39.3 & 33.0 & 6.3 & $\begin{array}{l}0.2 \\
9.2\end{array}$ & 19.6 & 1.62 \\
\hline & $\mathrm{SD}^{6}$ & 1.49 & 1.18 & 0.67 & 0.61 & 0.88 & 0.907 \\
\hline
\end{tabular}

${ }^{1}$ Hemicellulose.

${ }^{2}$ Condensed tannins.

${ }^{3}$ Concentrations of tannin were determined on freeze-dried forage sampled before either wilting or ensiling; therefore, the same concentration of CT was associated with both conservation methods for each cultivar on each harvest date.

${ }^{4}$ Spredor is an alfalfa cultivar containing no tannin; all other cultivars are birdsfoot trefoil.

${ }^{5}$ Mean of all 24 forages for NDF, ADF, HEMI, lignin, and CP; mean of 12 forages for CT.

${ }^{6}$ Standard deviation of the mean for all 24 forages.

or LADJ calculation protocols are found in Table 2. Fraction A decreased linearly $(P<0.01)$ with $\mathrm{CT}$, but this response was not homogeneous across conservation types (Figure 1A), yielding differing intercepts $(P<$ $0.01)$, and a tendency for different slopes $(P=0.07)$. For $\mathrm{HY}$ forages, the relationship between fraction $\mathrm{A}$ and CT was not affected $(P \geq 0.33)$ by harvest, decreasing across all hays by 1.8 percentage units of $\mathrm{CP}$ for each percentage unit of CT in forage DM. For SLG, fraction A exhibited homogeneous slopes $(P=0.53)$ across harvests, but intercepts differed $(P=0.03)$ with HRVST 2 being 5.8 percentage units of $\mathrm{CP}$ greater than observed for HRVST 1. Due to proteolytic activity during ensiling, intercepts for SLG were 22.0 and 27.8 percentage units of CP greater for HRVST 1 and HRVST 2, respectively, than observed for HY. Respective slopes for SLG were -3.8 and -5.0 percentage units of CP for each percentage unit of $\mathrm{CT}$ in forage $\mathrm{DM}$, which were 2- to 3-fold greater in magnitude than observed for $\mathrm{HY}$ $(P=0.07)$. This suggests that $\mathrm{CT}$ reduced proteolysis to a greater degree in SLG than in HY during forage conservation. Similar differences between conservation methods have been observed previously for fraction A in alfalfa forages (Hristov and Sandev, 1998), and for both alfalfa and BFT (Grabber et al., 2011); in each case, autolysis during fermentation yielded a substantially greater percentage of CP in soluble forms for silages. Our mean fraction A values of 55.1 and $81.5 \%$ of $\mathrm{CP}$ for alfalfa $\mathrm{HY}$ and SLG, respectively, were greater than NRC (2001) estimates of $44.3 \%$ for hay and $57.3 \%$ for silage from a mid-maturity legume containing $21.9 \% \mathrm{CP}$ (and presumably lacking CT). The especially large fraction A in our alfalfa SLG could be attributed to vacuum ensiling in laboratory silos, which often promotes anaerobic cell lysis, and greater proteolysis in laboratory silages than would commonly occur in farm-scale silos (R. E. Muck, USDA-ARS, US Dairy Forage Research Center, Madison, WI, personal communication). Reductions in fraction A in response to $\mathrm{CT}$ were comparable to what was observed in our previous work with alfalfa and BFT hays and silages (Grabber et al., 2011). 
Table 2. Ruminal in situ degradation characteristics of CP (with discrete lag) for 6 legumes conserved as either wilted hay or silage following 2 independent harvests at Prairie du Sac, Wisconsin ${ }^{1}$

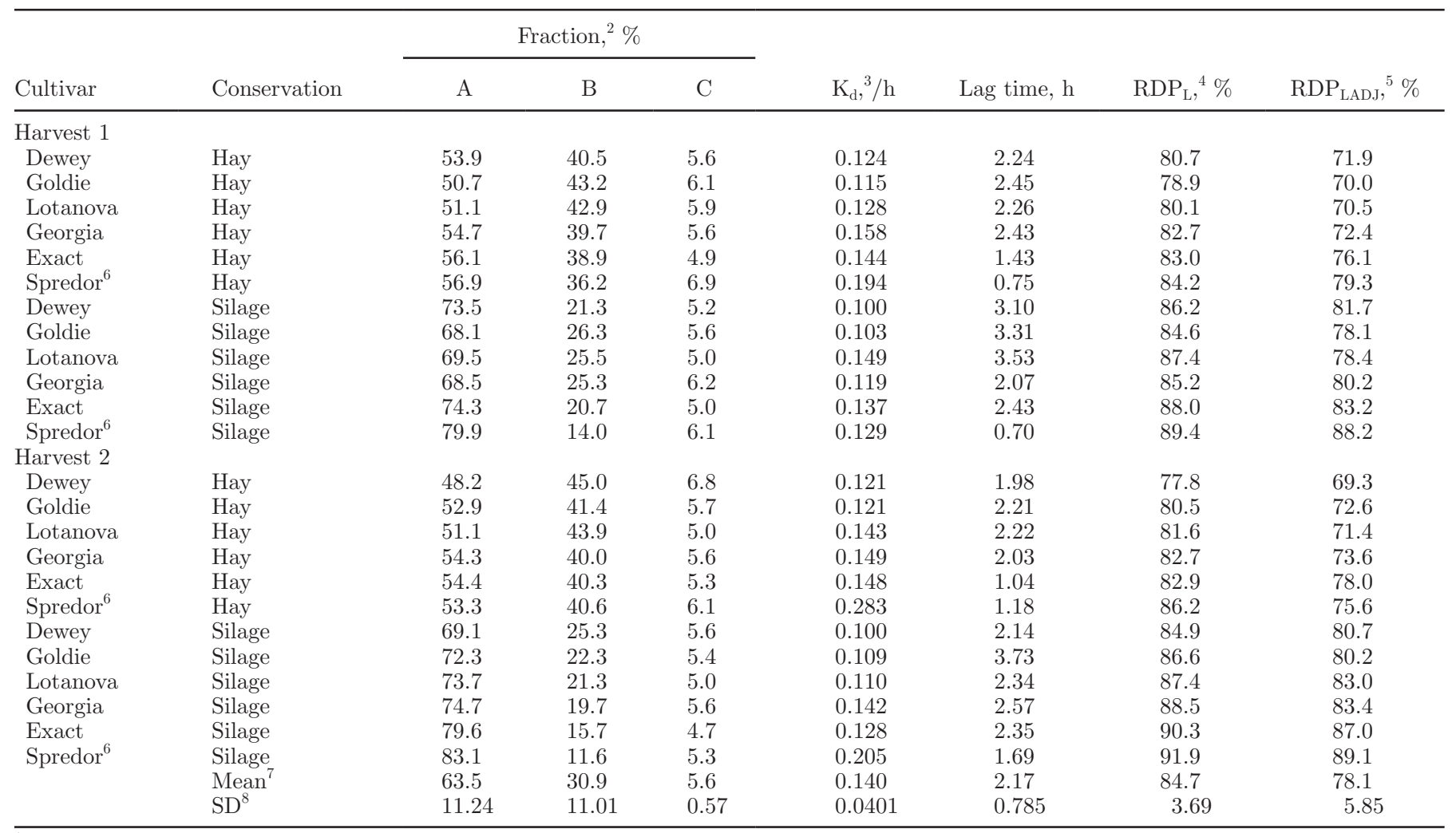

${ }^{1}$ Individual ruminal disappearance curves were fitted with a discrete lag time.

${ }^{2} \mathrm{~A}=$ immediately soluble fraction; $\mathrm{B}=$ fraction degradable at a measurable rate; $\mathrm{C}=$ undegradable fraction.

${ }^{3}$ Where $\mathrm{K}_{\mathrm{d}}=$ fractional degradation rate.

${ }^{4} \mathrm{RDP}_{\mathrm{L}}=$ effective ruminal degradability of $\mathrm{CP}$, where $\mathrm{RDP}_{\mathrm{L}}=\mathrm{A}+\mathrm{B} \times\left[\mathrm{K}_{\mathrm{d}} /\left(\mathrm{K}_{\mathrm{d}}+\mathrm{Kp}\right)\right]$. Individual ruminal disappearance curves were fitted with a lag time built into the model. Passage rate $(\mathrm{Kp})$ was arbitrarily set to $0.06 / \mathrm{h}$.

${ }^{5} \mathrm{RDP}_{\mathrm{LADJ}}=$ effective ruminal degradability of $\mathrm{CP}$ calculated with the lag adjustment, where $\mathrm{RDP}_{\mathrm{LADJ}}=\mathrm{A}+\mathrm{B} \times\left[\mathrm{K}_{\mathrm{d}} /\left(\mathrm{K}_{\mathrm{d}}+\mathrm{Kp}\right)\right] \times\left(\mathrm{e}^{\left.-\left(\mathrm{K}_{\mathrm{d}}+\mathrm{Kp}\right) \times \operatorname{lag}\right)}\right.$ (McDonald, 1981).

${ }^{6}$ Spredor is an alfalfa cultivar containing no tannin; all other cultivars are birdsfoot trefoil, and contain varying concentrations of tannins.

${ }^{7}$ Mean for all 24 forages.

${ }^{8}$ Standard deviation of the mean for all 24 forages.

Omitting the discrete lag time (NL protocol; Figure 1B) had little effect on the relationships between fraction A and CT relative to protocols fitting a lag time. Tests of homogeneity indicated that conservation types differed on the basis of intercept $(P<0.01)$, but not slope $(P=0.14)$. Within conservation types, responses for hays did not differ across harvests $(P \geq 0.48)$; however, silage harvests differed on the basis of intercept $(P=0.03)$, but exhibited a common slope $(P=0.65)$. This is not surprising because quantification of fraction A is largely driven by solubility in water, which should be less affected by curve fitting than other kinetic characteristics; however, a substantial improvement in the coefficient of determination for fraction A was observed for HY fit without a lag $\left(\mathrm{R}^{2}=0.61\right)$ compared with that determined with the $\mathrm{L}$ disappearance model that fit a discrete lag time $\left(\mathrm{R}^{2}=0.44\right.$; Figure $\left.1 \mathrm{~A}\right)$.

Fraction B. In general, the effects of conservation method and CT on fraction B were mirror-opposite responses compared with those described for fraction A. With L or LADJ procedures (Figure 2A), regression equations for SLG and HY differed on the basis of intercept $(P<0.01)$ and slope $(P=0.05)$. For HY forages, the relationship between fraction $\mathrm{B}$ and $\mathrm{CT}$ was not affected $(P \geq 0.23)$ by harvest, increasing across all hays by 1.9 percentage units of $\mathrm{CP}$ for each percentage unit of CT in forage DM. For SLG, fraction B exhibited homogeneous slopes $(P=0.67)$ across harvests, but intercepts differed $(P=0.03)$, with HRVST 1 being 4.9 percentage units of $\mathrm{CP}$ greater than observed for 


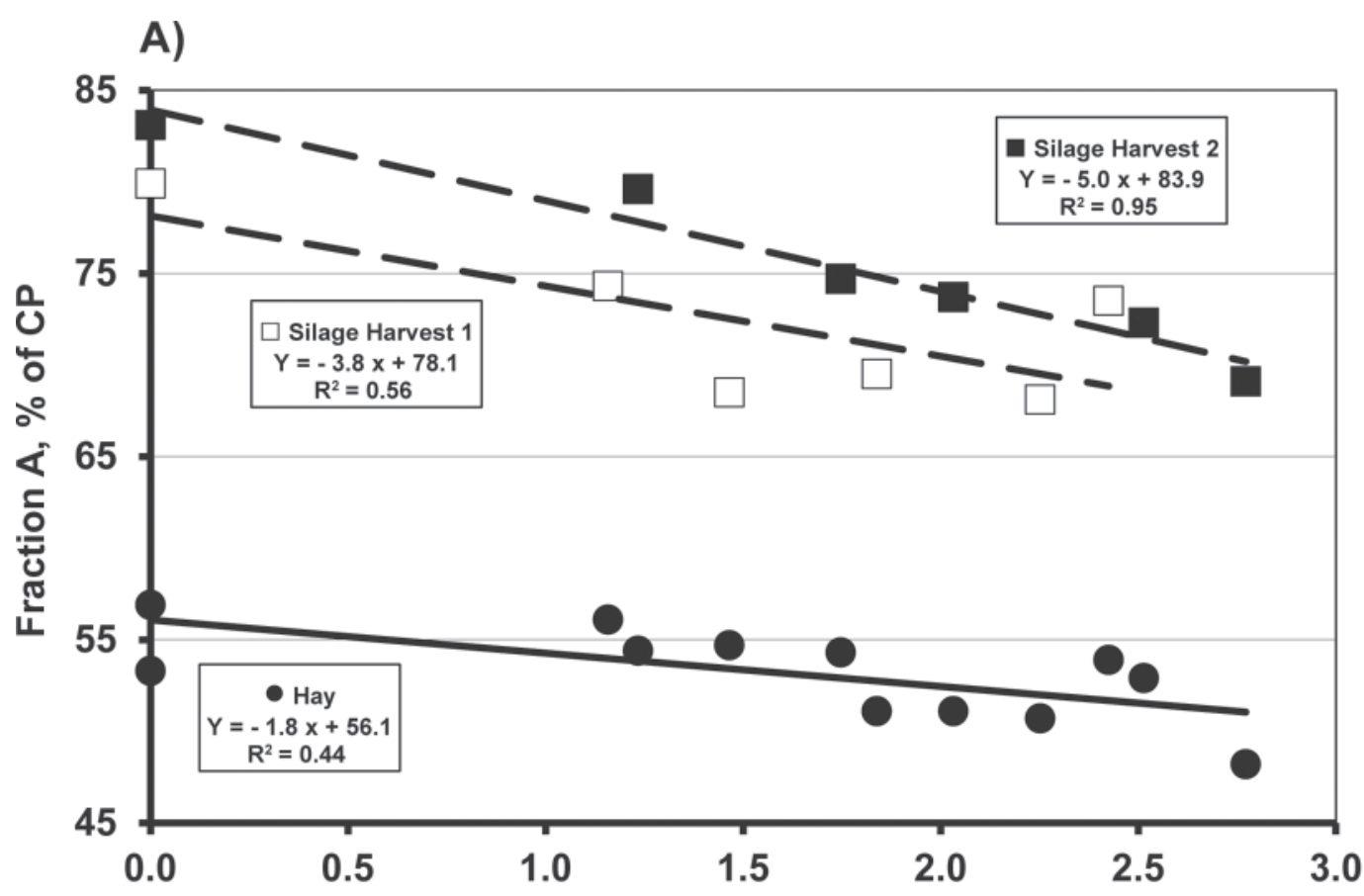

B)

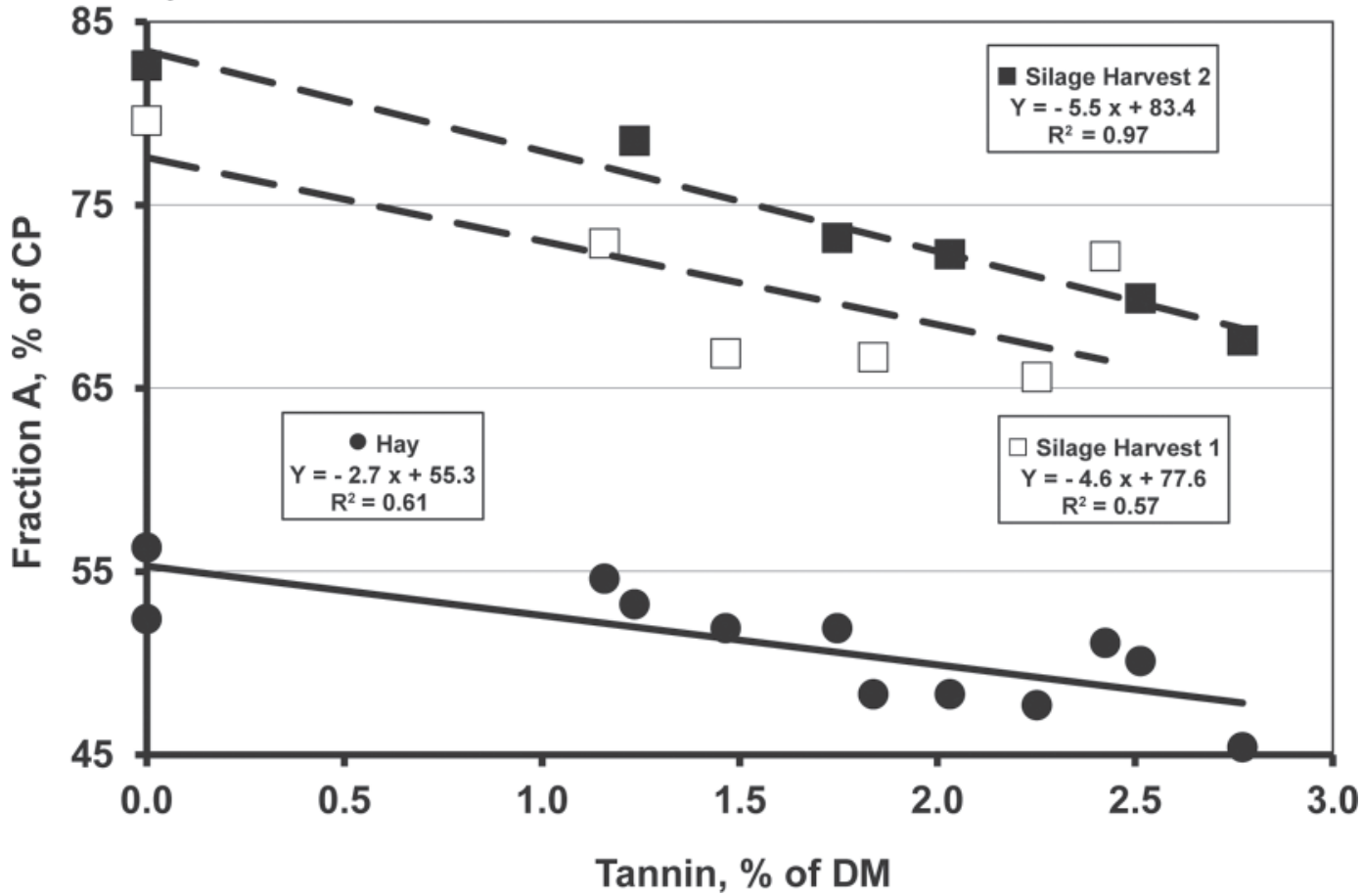

Figure 1. Relationships between fraction A (immediately soluble fraction; $\%$ of $\mathrm{CP}$ ) and concentrations of condensed tannins for alfalfa and birdsfoot trefoil forages. Estimates of fraction A were derived from ruminal CP disappearance curves fitted with a discrete lag time (1A, top) or without a lag time (1B, bottom).

HRVST 2. Respective intercepts for SLG were 22.1 and 27.0 percentage units of CP less for HRVST 1 and HRVST 2 than observed for HY; presumably, this re- sponse was due to extensive proteolytic activity that occurs during ensiling. Considered collectively across harvests, slopes for SLG increased by 4.3 percentage 
units of $\mathrm{CP}$ for each percentage unit of $\mathrm{CT}$ in forage DM [about 2-fold greater than for $\mathrm{HY}(P=0.05)$ ], again suggesting that CT had a greater effect in protecting protein from proteolysis during conservation as SLG compared with HY. Similar differences between conservation methods have been observed previously for fraction B in alfalfa forages (Hristov and Sandev, 1998), and for both alfalfa and BFT (Grabber et al., 2011), with autolysis during fermentation resulting in a substantially lower percentage of $\mathrm{CP}$ in forms degradable in the rumen at a measurable rate. Our mean fraction B values of $38.4 \%$ for alfalfa $\mathrm{HY}$ and $12.8 \%$ for alfalfa SLG were less than respective estimates of 46.9 and $35.3 \%$ of $\mathrm{CP}$ for hay and silage from midmaturity legumes containing $21.9 \%$ CP (NRC, 2001). The particularly small fraction B in our alfalfa silages could again be attributed to ensiling in laboratory silos. Similar increases in fraction B due to CT were also observed in our previous work with alfalfa and BFT hays and silages (Grabber et al., 2011).

Generally, use of NL procedures (Figure 2B) had little effect on the relationship between fraction $\mathrm{B}$ and $\mathrm{CT}$ relative to the disappearance model fitting a discrete lag time. Tests of homogeneity indicated that conservation types differed on the basis of intercept $(P<0.01)$, but not slope $(P=0.14)$. Within conservation types, responses for hays were similar across harvests $(P \geq$ $0.25)$. In contrast, silage harvests exhibited a common slope $(P=0.83)$, but differed on the basis of intercept $(P=0.04)$. Principal discrepancies between the NL and $\mathrm{L}$ methods included an improved fit for $\mathrm{HY}\left(\mathrm{R}^{2}=0.68\right)$ compared with that observed with a discrete lag time $\left(\mathrm{R}^{2}=0.52\right)$, and no evidence of heterogeneity of slopes $(P=0.14)$ between HY and SLG, although the magnitude of slopes for SLG were 1.7 to 1.8 times greater than observed for HY.

Fraction $\boldsymbol{C}$. The percentage of the total CP pool that was unavailable in the rumen was largely unaffected by concentrations of CT (Figures $3 \mathrm{~A}$ and $3 \mathrm{~B}$ ). Overall, mean concentrations (mean $\pm \mathrm{SD}$ ) of fraction $\mathrm{C}$ were $5.6 \pm 0.57 \%$ of $\mathrm{CP}$ when ruminal $\mathrm{CP}$ disappearance was fitted with a discrete lag time, and $5.0 \pm$ $0.61 \%$ when a discrete lag time was omitted from computational procedures (Tables 2 and 3, respectively). When a lag time was fitted (Figure 3A), fraction C was not related to $\mathrm{CT}(P=0.53)$. Without a lag time (Figure 3B), fraction $\mathrm{C}$ tended to decrease $(P=0.09)$ in a weak negative relationship with $\mathrm{CT}$, but slopes $(P=0.84)$ and intercepts $(P=0.60)$ did not differ on the basis of conservation type. Our mean estimate of fraction C for alfalfa HY and SLG fitted without a discrete lag time (6.1\% of CP; Table 2$)$ was only about 2 percentage points less than the corresponding estimates for mid-maturity legume hay $(8.8 \%$ of
CP) or silage (7.4\% of CP; NRC, 2001). The overall absence of a relationship with fraction $\mathrm{C}$ suggests that concentrations of $\mathrm{CT}$ ranging from 0 to $2.77 \%$ of $\mathrm{DM}$ in BFT forages are not likely to increase concentrations of indigestible protein. Unfortunately, this potential problem has been noted in work with other CT-containing species (Waghorn, 2008; Patra and Saxena, 2011), but feeding studies with sheep also have shown that CT in fresh BFT does not affect the gastrointestinal digestion of CP adversely (Waghorn et al., 1987).

$\boldsymbol{K}_{d}$. Unlike fractions A, B, and C, estimates of $\mathrm{K}_{\mathrm{d}}$ were sharply affected by curve-fitting procedures. Considered over all 24 forages, $K_{d}$ fitted with a lag time was $33 \%$ more rapid (mean \pm SD; $0.140 \pm 0.0401$; Table 2) than estimates calculated without a lag time $(0.105 \pm 0.0288 / \mathrm{h}$; Table 3$)$. This likely occurred because loss of fraction B forage proteins from Dacron bags was extended over a longer interval of time when ruminal disappearance was initiated mathematically at $0 \mathrm{~h}$, which was the case if a discrete lag time was omitted from the disappearance model. Furthermore, $\mathrm{K}_{\mathrm{d}}$ fitted with a lag time was $26 \%$ more rapid for $\mathrm{HY}$ $(0.152 \pm 0.0465 / \mathrm{h})$ than SLG $(0.128 \pm 0.0295 / \mathrm{h})$, and a similar relationship between HY $(0.116 \pm 0.0318 / \mathrm{h})$ and SLG $(0.094 \pm 0.0213 / \mathrm{h})$ was observed when $\mathrm{K}_{\mathrm{d}}$ was fitted without a lag time. Previous studies have also reported more rapid estimates of $\mathrm{K}_{\mathrm{d}}$ for alfalfa and BFT conserved as hay compared with silage (Hristov and Sandev, 1998; Grabber et al., 2011). Estimates of $\mathrm{K}_{\mathrm{d}}$ for a mid-maturity legume $(0.179$ and $0.122 / \mathrm{h}$ for hay and silage, respectively; NRC, 2001) agreed closely with our estimates for alfalfa from HRVST 1 (Table 2), but not for HRVST 2, where longer lag times may have contributed to more rapid estimates of $\mathrm{K}_{\mathrm{d}}$.

When fitted with a discrete lag (Figure 4A), tests of homogeneity for the linear relationship between $\mathrm{K}_{\mathrm{d}}$ and CT indicated that intercepts differed $(P=0.02)$ between conservation types. Slopes for $\mathrm{K}_{\mathrm{d}}$ declined linearly with CT $(P<0.01)$, and conservation type weakly affected these responses $(P=0.09)$, with HY tending to have a more negative slope than SLG $(-0.044 / \mathrm{h}$ vs. $-0.024 / \mathrm{h}$ per percentage unit of $\mathrm{CT}$ in forage $\mathrm{DM}$ ). Within conservation type, harvests for $\mathrm{HY}$ tended to differ on the basis of intercept $(P=0.06)$, whereas SLG tended to exhibit heterogeneous slopes $(P=0.06)$. In part, these tendencies, as well as the moderate coefficients of determination $\left(\mathrm{R}^{2}=0.72\right.$ and 0.55$)$ for conservation types can be explained by the sharply differing estimates of $K_{d}$ across harvests for alfalfa that were not observed for BFT forages containing CT (Figure 4A).

When fitted without a lag time, HY and SLG exhibited differing $(P<0.01)$ intercepts for $\mathrm{K}_{\mathrm{d}}$ that were also coupled with a tendency $(P=0.08)$ for a more negative slope for HY (Figure 4B). Within 


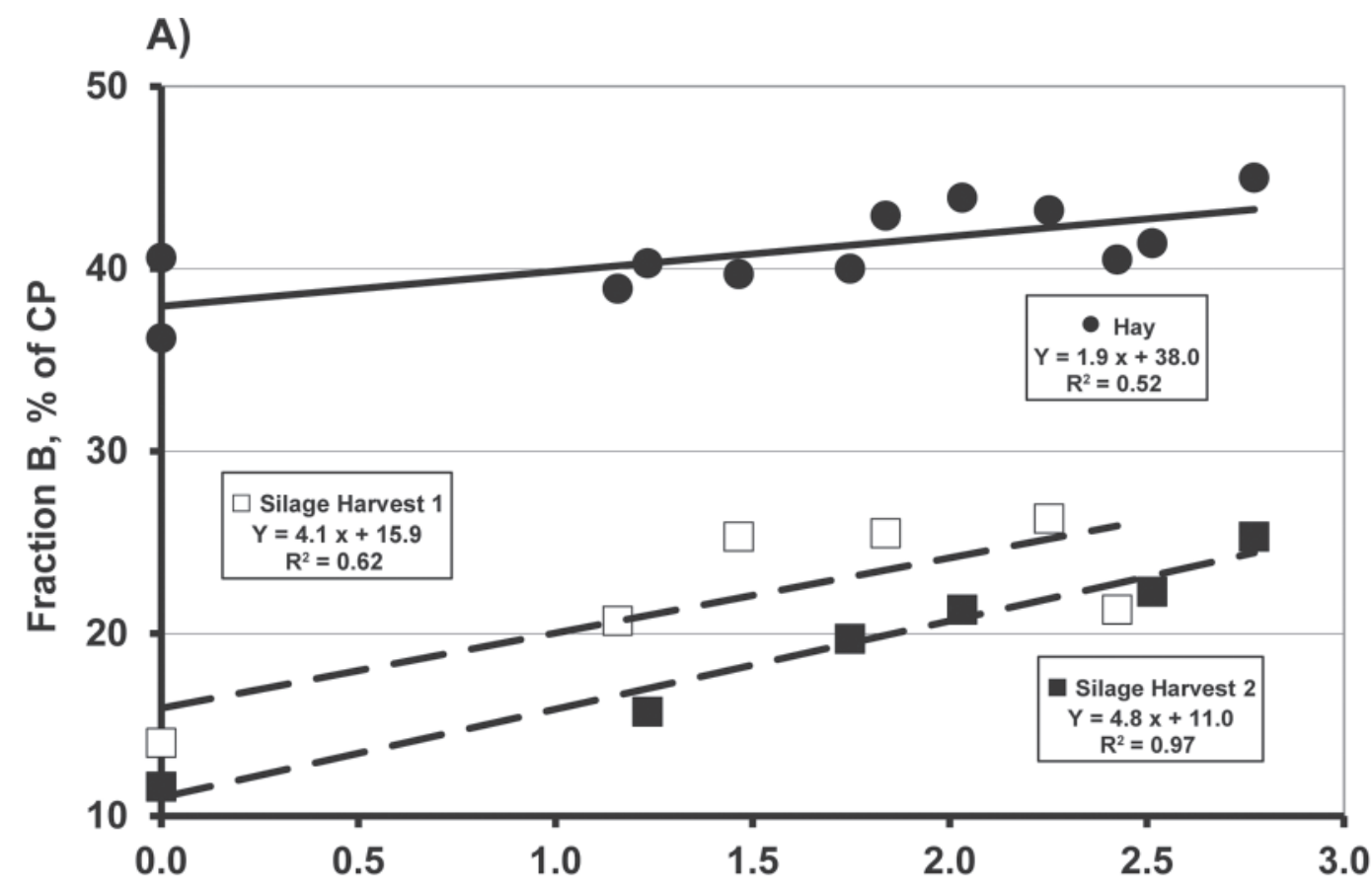

B)

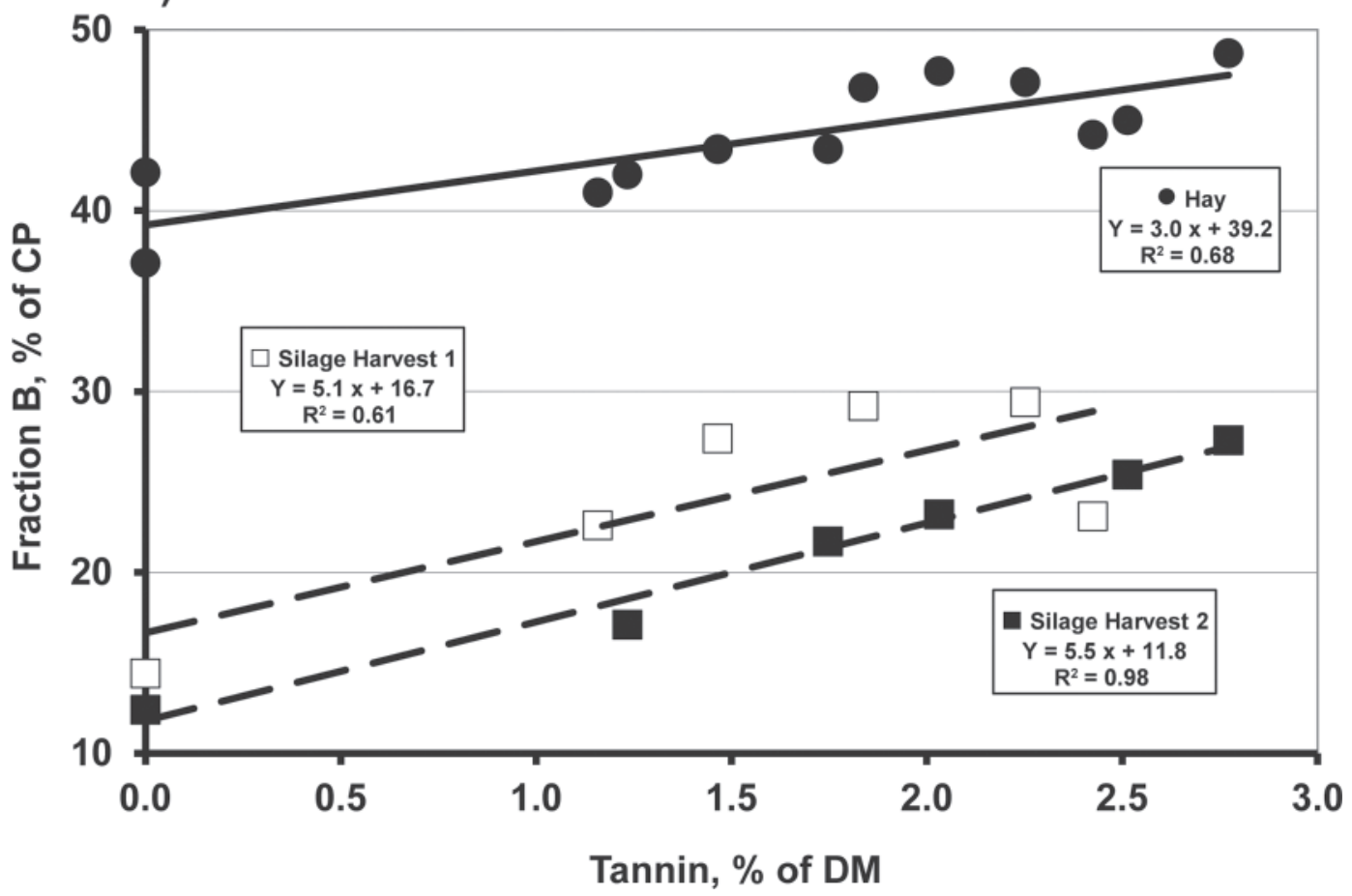

Figure 2. Relationships between fraction B (fraction degradable at a measurable rate; $\%$ of $\mathrm{CP}$ ), and concentrations of condensed tannins for alfalfa and birdsfoot trefoil forages. Estimates of fraction B were derived from ruminal CP disappearance curves fitted with a discrete lag time $(2 \mathrm{~A}$, top) or without a lag time (2B, bottom).

conservation types, the relationships between $\mathrm{K}_{\mathrm{d}}$ and CT differed on the basis of harvest, which were solely explained by differences in intercept $(P \leq 0.01)$, but not slope $(P \geq 0.17)$. Segregating regression relationships on the basis of harvest within conservation type improved coefficients of determination, which were 


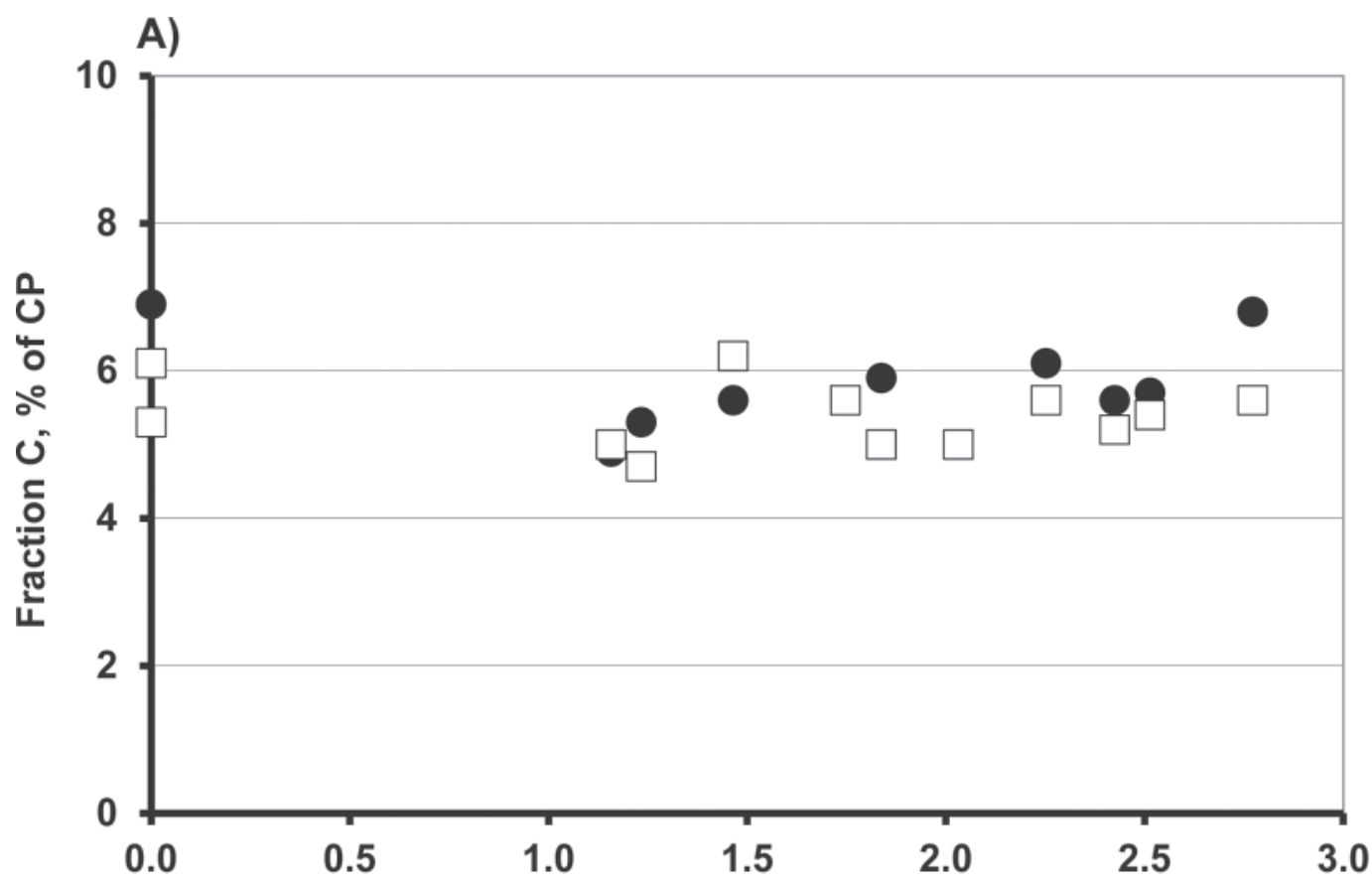

B)

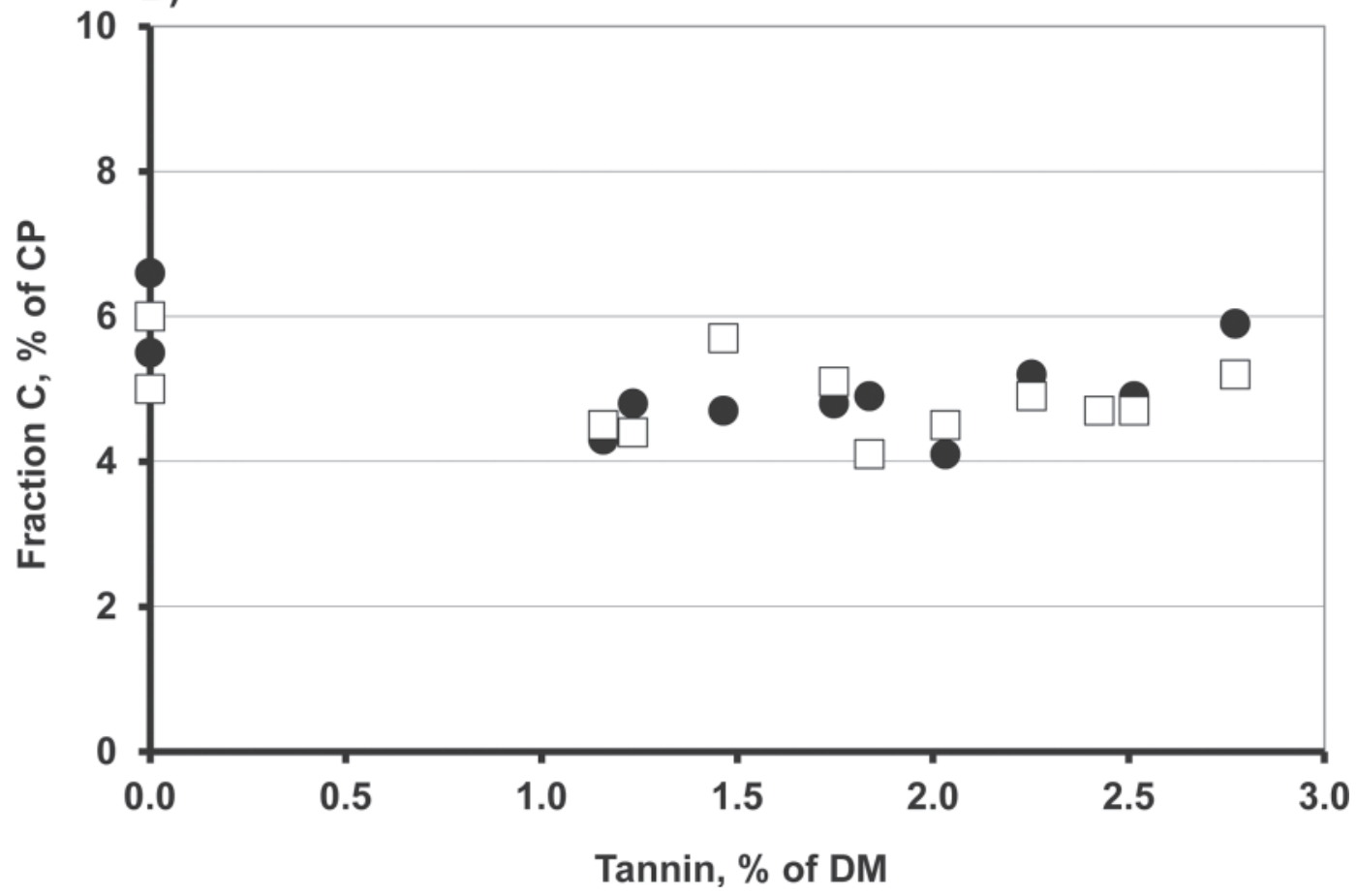

Figure 3. Relationships between fraction $\mathrm{C}$ (undegradable fraction; \% of $\mathrm{CP}$ ) and concentrations of condensed tannins (CT) for alfalfa and birdsfoot trefoil forages. Estimates of fraction $\mathrm{C}$ were derived from ruminal CP disappearance curves fitted with a discrete lag time (3A, top) or without a lag time (3B, bottom). For Figures 3A and 3B, hays are represented by black circles $(\bullet)$ and silages by open squares $(\square)$. When a lag time was fitted for ruminal disappearance curves $(3 \mathrm{~A})$, fraction $\mathrm{C}$ was not related to $\mathrm{CT}(P=0.53)$. Without a lag time $(3 \mathrm{~B})$, fraction $\mathrm{C}$ tended to decline $(P=0.09)$ in a weak negative relationship with $\mathrm{CT}$, but slopes $(P=0.84)$ and intercepts $(P=0.60)$ did not differ on the basis of conservation type. 
Table 3. Ruminal in situ degradation characteristics of CP (without discrete lag time) for 6 legumes conserved as either wilted hay or silage following 2 independent harvests at Prairie du Sac, Wisconsin ${ }^{1}$

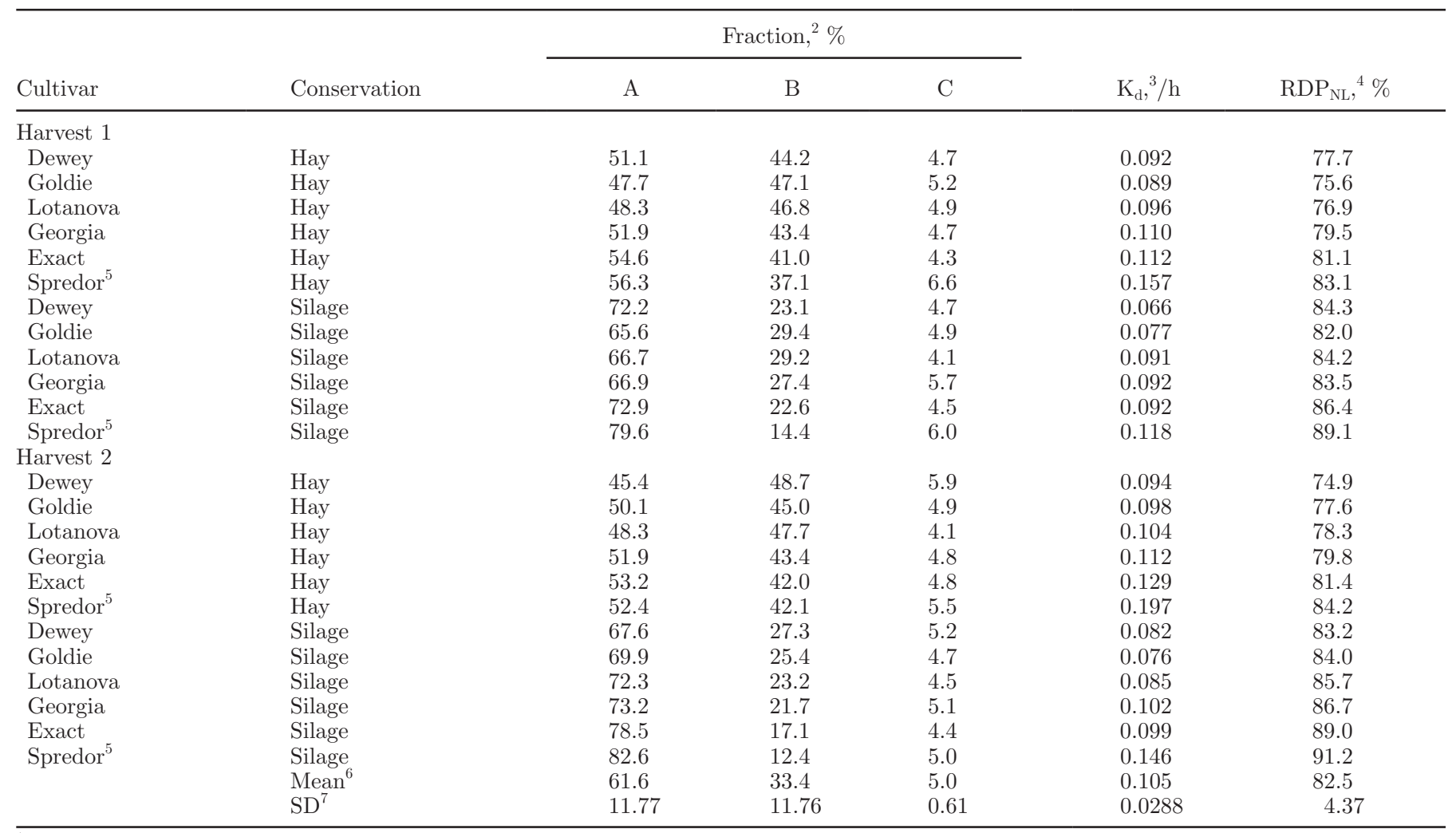

${ }^{1}$ Ruminal disappearance curves were fitted without a discrete lag time.

${ }^{2} \mathrm{~A}=$ immediately soluble fraction; $\mathrm{B}=$ fraction degradable at a measurable rate; $\mathrm{C}=$ undegradable fraction.

${ }^{3}$ Where $\mathrm{K}_{\mathrm{d}}=$ fractional degradation rate.

${ }^{4} \mathrm{RDP}_{\mathrm{NL}}=$ effective ruminal degradability of $\mathrm{CP}$, where $\mathrm{RDP}_{\mathrm{NL}}=\mathrm{A}+\mathrm{B} \times\left[\mathrm{K}_{\mathrm{d}} /\left(\mathrm{K}_{\mathrm{d}}+\mathrm{Kp}\right)\right]$. Individual ruminal disappearance curves were fitted without a lag time built into the model. Passage rate $(\mathrm{Kp})$ was arbitrarily set to $0.06 / \mathrm{h}$ to best reflect expected ruminal passage for lactating dairy cows.

${ }^{5}$ Spredor is an alfalfa cultivar containing no tannin; all other cultivars are birdsfoot trefoil, and contain varying concentrations of tannins.

${ }^{6}$ Mean for all 24 forages.

${ }^{7}$ Standard deviation for all 24 forages.

$\geq 0.91$ for all 4 combinations of conservation type and harvest.

Lag Time. Discrete lag time increased $(P<0.01)$ with concentrations of CT (Figure 5), and intercepts differed between conservation types $(P=0.01)$, but slopes did not $(P=0.48)$. Within conservation type, individual harvests did not affect $(P \geq 0.10)$ relationships between lag time and CT. Overall, discrete lag times ranged from 0.70 to $3.73 \mathrm{~h}$ (Table 2), and increased by an average of $0.61 \mathrm{~h}$ per percentage unit of $\mathrm{CT}$ in the forage DM for SLG and HY considered collectively. Although readily acknowledging the experimental limitations of the in situ procedures used in this project, $\mathrm{CT}$ appeared to delay the onset of ruminal protein degradation in conserved BFT.

Effective Ruminal Protein Disappearance. Averaged over all 24 forages, mean estimates $( \pm \mathrm{SD})$ for
$\mathrm{RDP}_{\mathrm{L}}, \mathrm{RDP}_{\mathrm{LADJ}}$, and $\mathrm{RDP}_{\mathrm{NL}}$ were $84.7 \pm 3.69,78.1 \pm$ 5.85 , and $82.5 \pm 4.37 \%$ of $\mathrm{CP}$, respectively (Tables 2 and 3 ). These estimates are consistent with previous evaluations for these species in studies conducted in Wisconsin (Hoffman et al., 1993; Broderick and Albrecht, 1997; Grabber et al., 2011). For $\mathrm{RDP}_{\mathrm{L}}$ (Figure 6 ), tests of homogeneity indicated that the relationships between $\mathrm{RDP}_{\mathrm{L}}$ and $\mathrm{CT}$ differed between conservation types on the basis of intercept $(P<0.01)$. Slopes did not differ $(P=0.56)$ between conservation types, thereby indicating that $\mathrm{RDP}_{\mathrm{L}}$ was reduced by 2.1 percentage units of $\mathrm{CP}$ for every percentage unit of $\mathrm{CT}$ in forage DM when intercept differences were ignored, and all forages were considered collectively yielding a common slope. Differences in intercept likely reflect the autolysis of proteins during silage fermentation that does not occur as extensively during conservation as HY. For HY, 


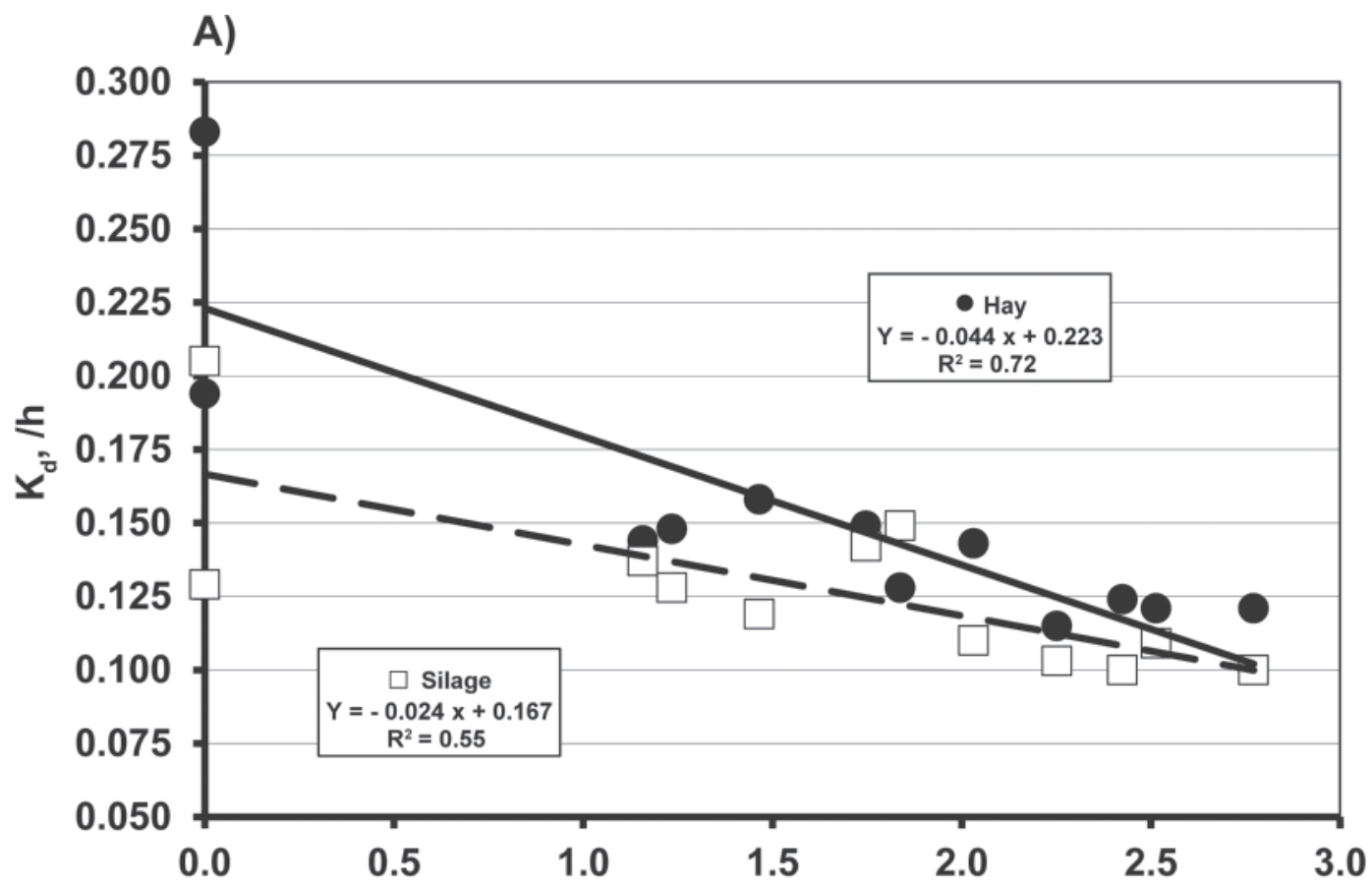

B)

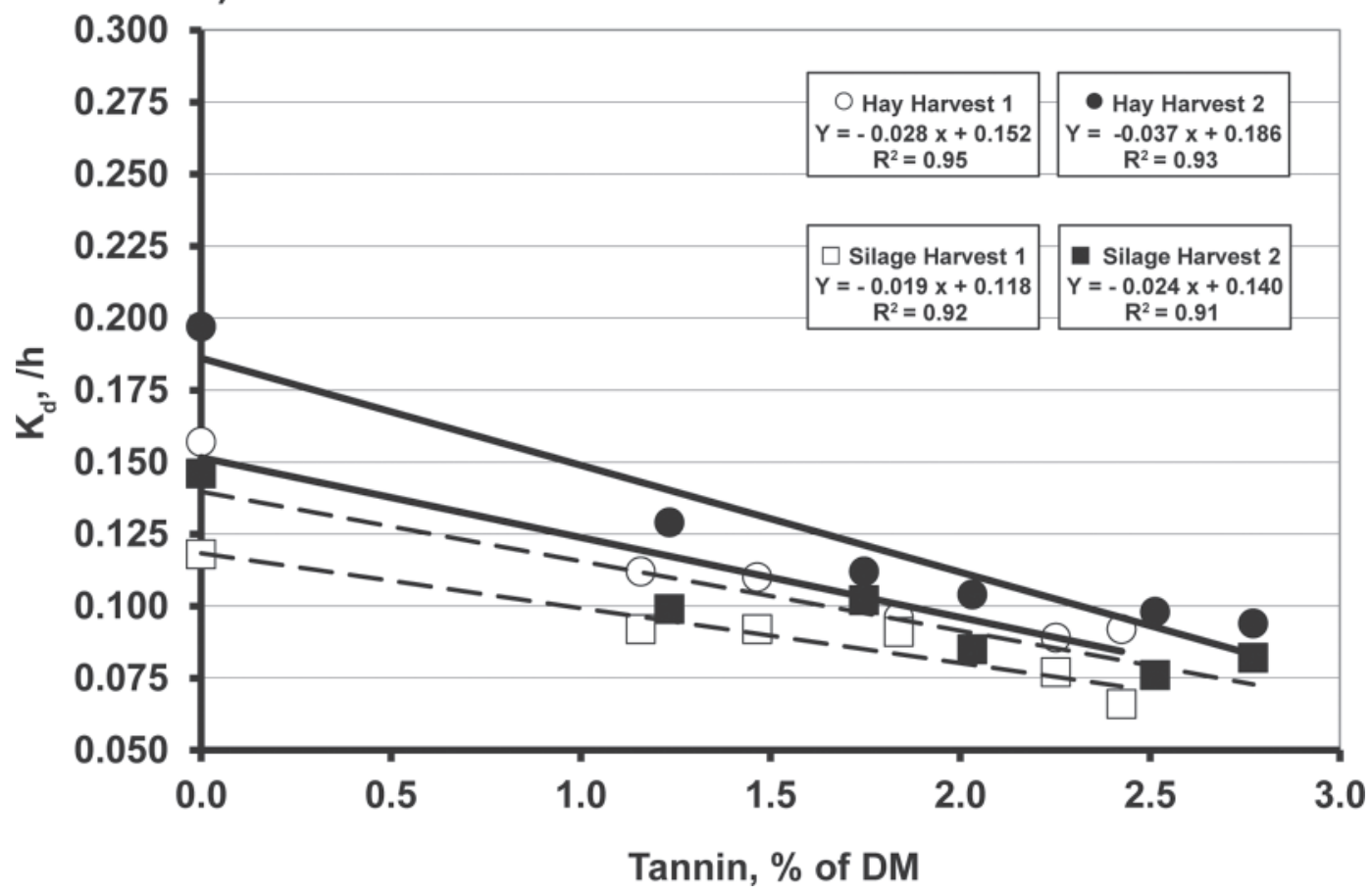

Figure 4. Relationships between ruminal degradation rate $\left(\mathrm{K}_{\mathrm{d}} ; / \mathrm{h}\right)$ and concentrations of condensed tannins for alfalfa and birdsfoot trefoil forages. Estimates of $K_{d}$ were derived from ruminal CP disappearance curves fitted with a discrete lag time (3A, top) or without a lag time (3B, bottom).

regressions for harvests were homogeneous $(P \geq 0.21)$, thereby yielding a collective response characterized by a relatively high coefficient of determination $(\mathrm{n}=12$; $\left.\mathrm{Y}=-2.3 \mathrm{x}+85.5 ; \mathrm{R}^{2}=0.82\right)$, and suggests a continu- ity of response across the 2 forage species. For SLG, harvests differed on the basis of intercept $(P=0.01)$, with HRVST 2 exceeding HRVST 1 (92.5 vs. 89.2\%); however, slopes did not differ $(P=0.25)$. 


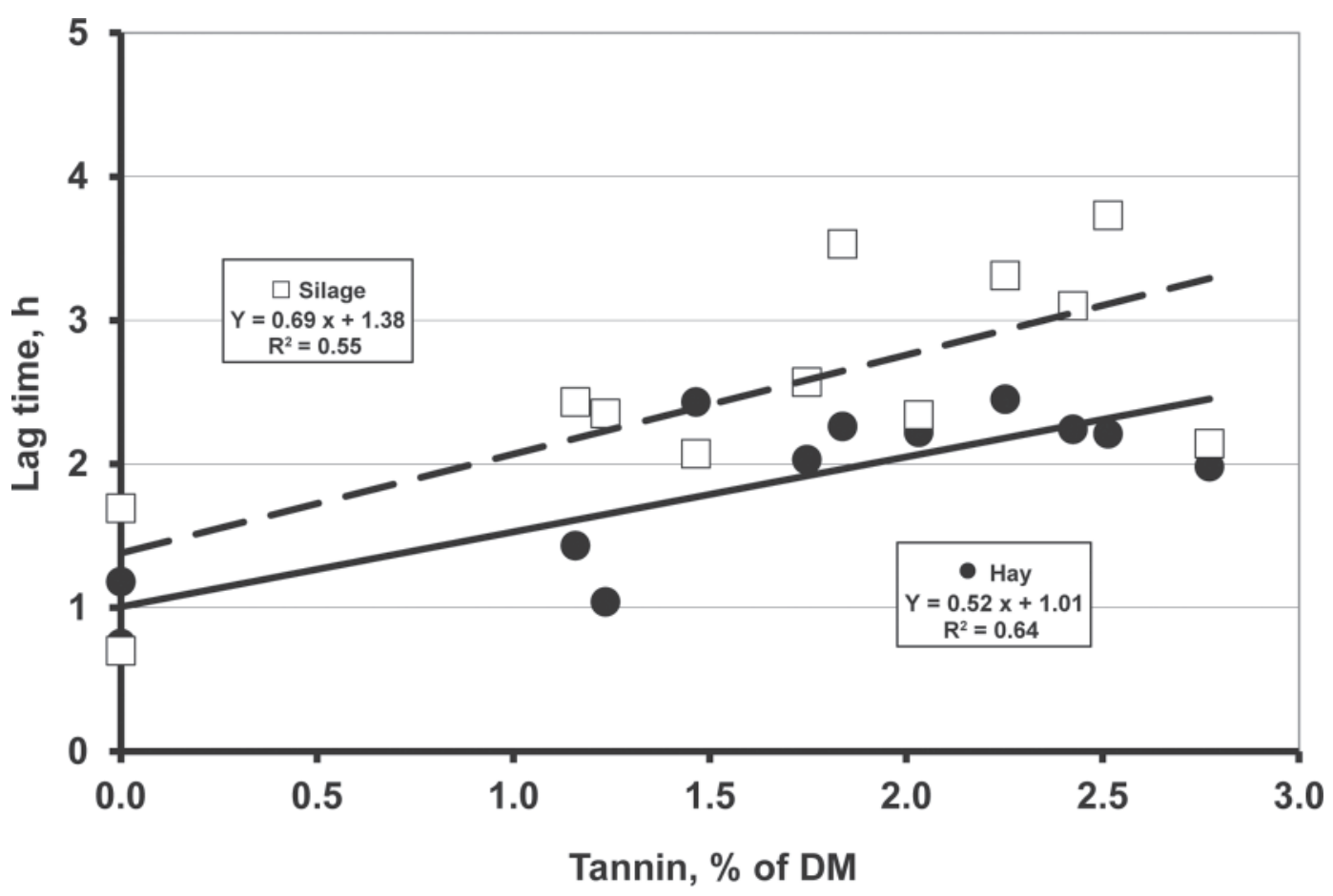

Figure 5. Relationships between lag time (h) and concentrations of condensed tannins for alfalfa and birdsfoot trefoil forages.

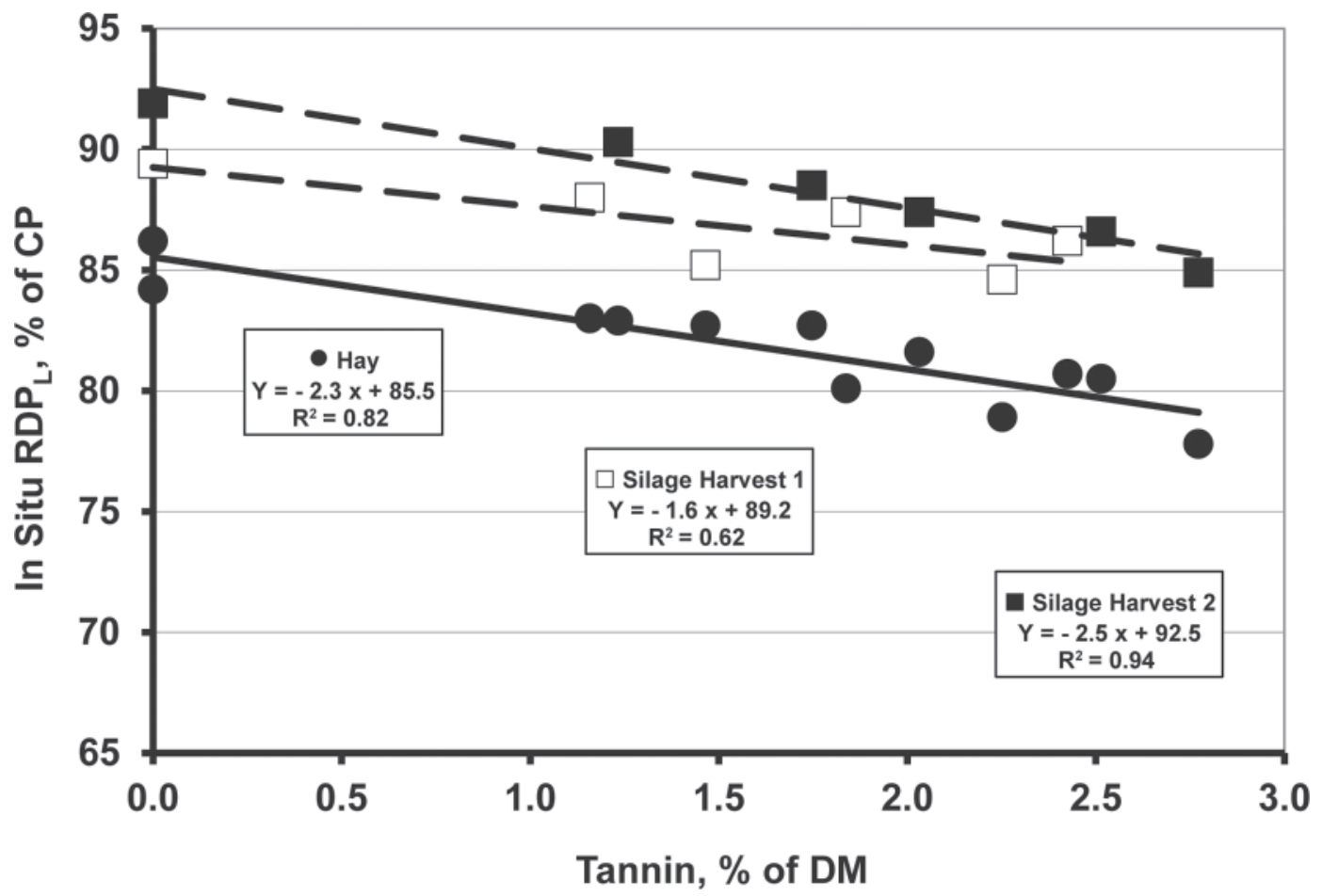

Figure 6. Relationships between effective ruminal in situ CP degradability (RDP with a discrete lag, $\mathrm{RDP}_{\mathrm{L}} ; \%$ of $\mathrm{CP}$ ) and concentrations of condensed tannins for alfalfa and birdsfoot trefoil forages. Ruminal CP disappearance curves were fitted with a lag time, but lag time was not included in the calculation of $\mathrm{RDP}_{\mathrm{L}}$, where $\mathrm{RDP}_{\mathrm{L}}=\mathrm{A}+\left[\mathrm{B} \times \mathrm{K}_{\mathrm{d}} /\left(\mathrm{K}_{\mathrm{d}}+0.06\right)\right]$, where $\mathrm{A}$ and $\mathrm{B}$ are defined as the proportions of CP disappearing at rates too fast to measure, or at a measurable rate, respectively, and $\mathrm{K}_{\mathrm{d}}$ is the ruminal degradation rate. 


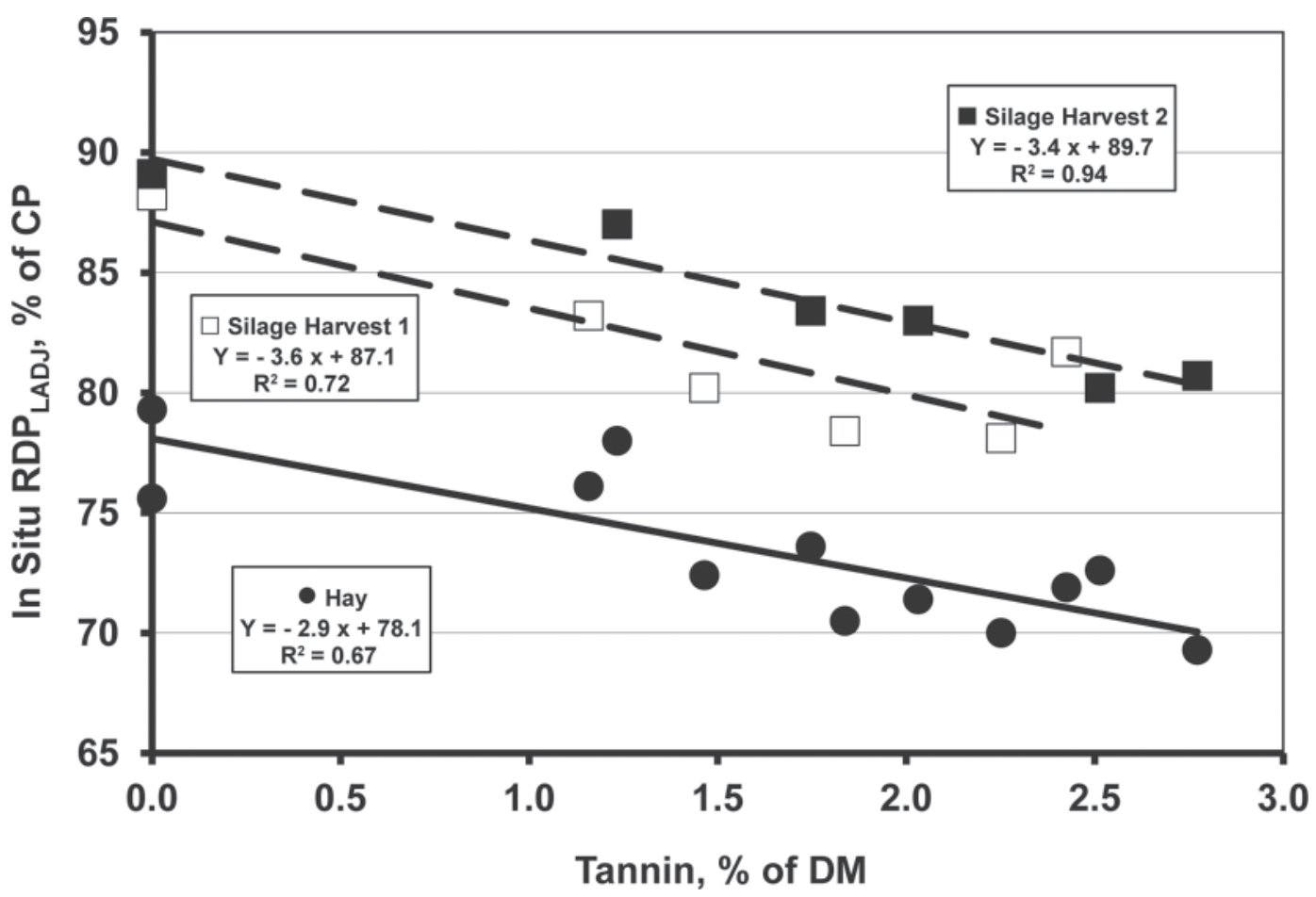

Figure 7. Relationships between effective ruminal in situ CP disappearance (RDP with a discrete lag with a lag adjustment, RDP $\mathrm{LADJ}$; $\%$ of $\mathrm{CP}$ ) and concentrations of condensed tannins for alfalfa and birdsfoot trefoil forages. Ruminal CP disappearance curves were fitted with a lag time, and $\mathrm{RDP}_{\mathrm{LADJ}}$ was calculated with an adjustment for lag time, where $\mathrm{RDP}_{\mathrm{LADJ}}=\mathrm{A}+\mathrm{B} \times\left[\mathrm{K}_{\mathrm{d}} /\left(\mathrm{K}_{\mathrm{d}}+\mathrm{Kp}\right)\right] \times\left(\mathrm{e}^{-\left(\mathrm{K}_{\mathrm{d}}+\mathrm{Kp}\right) \times \operatorname{lag}}\right)(\mathrm{McDonald}$, 1981), where A and B are defined as the proportions of CP disappearing at rates too fast to measure, or at a measurable rate, respectively; $\mathrm{K}_{\mathrm{d}}$ is the ruminal degradation rate; and $\mathrm{Kp}$ is the particulate passage rate that was set arbitrarily at $0.06 / \mathrm{h}$ to have relevance to passage kinetics in lactating dairy cows.

For $\mathrm{RDP}_{\mathrm{LADJ}}\left(\right.$ Figure 7 ) and $\mathrm{RDP}_{\mathrm{NL}}$ (Figure 8), the effects of conservation type and harvest had identical effects on linear regressions as those described for $\mathrm{RDP}_{\mathrm{L}}$. Specifically, conservation types differed $(P<$ $0.01)$ on the basis of intercept, but not slope $(P \geq$ $0.59)$. Therefore, slopes for all $(\mathrm{n}=24)$ forages considered collectively (common slope) were -3.1 and -2.8 percentage units of $\mathrm{CP}$ for every percentage unit of $\mathrm{CT}$ in the forage $\mathrm{DM}$ for the $\mathrm{RDP}_{\mathrm{LADJ}}$ and $\mathrm{RDP}_{\mathrm{NL}}$ models, respectively. For forages conserved as HY, no differences between individual harvests were detected $(P \geq$ $0.15)$. For SLG, intercepts for individual harvests differed $(P \leq 0.02)$, but slopes did not $(P \geq 0.50)$. Thus, although HY and SLG differed considerably in kinetic characteristics (fractions A, B, C, as well as lag time and $K_{d}$ ), the net effect of $C T$ in reducing RDP was similar for both types of conserved forage.

Concentrations of CT Needed to Optimize $\boldsymbol{R D P}$. As described above, numerous studies have examined the effects of CT on RDP for various forage legumes, but shortcomings in methodology often have obscured relationships between RDP and CT, and complicated attempts to identify the optimal concentrations of $\mathrm{CT}$ required to limit excessive RDP in legume hays and silages. In the current study, intercepts derived from linear regressions of $\mathrm{RDP}_{\mathrm{LADJ}}$ on $\mathrm{CT}$ (Figure 6) and individual estimates of RDP $\mathrm{LADJ}_{\mathrm{J}}$ for alfalfa forages containing no CT were comparable. The calculated intercepts were $78.1 \%$ of $\mathrm{CP}$ for $\mathrm{HY}$ and 87.1 and $89.7 \%$ of CP for SLG. By contrast, the NRC (2001) suggests that a comparable mid-maturity legume containing about $21 \% \mathrm{CP}$ would have an RDP of about $81 \%$ of CP for both hay and silage when DMI is set at $4 \%$ of BW. Therefore, differences between these NRC (2001) estimates of RDP and our intercepts computed from LADJ procedures were small for HY, but rather substantial for SLG. The differential between RDP estimates for HY and SLG observed consistently throughout this project is likely associated with proteolysis occurring during silage fermentation, which often is exacerbated when forages are ensiled in laboratory silos (R. E. Muck, USDA-ARS, US Dairy Forage Research Center, Madison, WI, personal communication).

Most importantly, regression slopes of $\mathrm{RDP}_{\text {LADJ }}$ on CT were not affected by conservation method, suggesting that CT suppressed the ruminal breakdown of protein to the same degree in both hay and silage (Figure 7). Likewise, if $\mathrm{RDP}_{\text {LADJ }}$ and CT data are both 


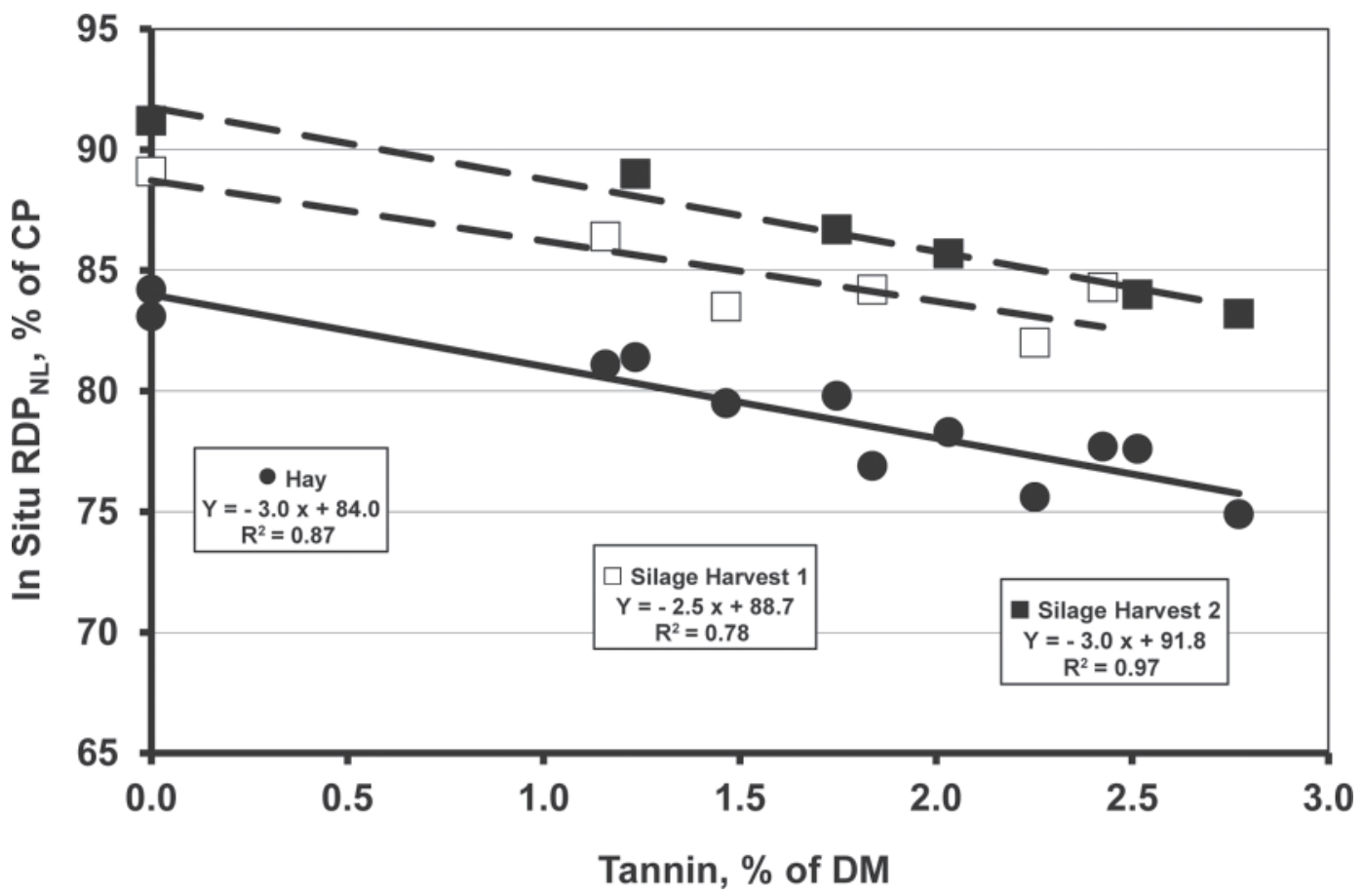

Figure 8. Relationships between effective ruminal in situ CP disappearance (RDP with no discrete lag, RDP $\mathrm{NL}_{\mathrm{NL}} \%$ of $\mathrm{CP}$ ) and concentrations of condensed tannins for alfalfa and birdsfoot trefoil forages. Ruminal CP disappearance curves were fitted without a lag time, and RDP $\mathrm{NL}_{\mathrm{N}}$ was calculated as $\mathrm{A}+\mathrm{B} \times\left[\mathrm{K}_{\mathrm{d}} /\left(\mathrm{K}_{\mathrm{d}}+\mathrm{Kp}\right)\right]$, where $\mathrm{A}$ and $\mathrm{B}$ are defined as the proportions of CP disappearing at rates too fast to measure, or at a measurable rate, respectively; $K_{d}$ is the ruminal degradation rate; and $\mathrm{Kp}$ is the particulate passage rate that was set arbitrarily at $0.06 / \mathrm{h}$ to have relevance to passage kinetics in lactating dairy cows.

expressed on a CP basis, then slopes from linear regressions indicate that each unit of CT protected an average of 0.61 units of CP in hay and silage from ruminal degradation. Accordingly, applying this relationship to a typical mid-maturity forage legume containing $21 \%$ CP (NRC, 2001) suggests that $3.8 \%$ of $\mathrm{CT}$ on a DM basis would be needed to reduce RDP from $81 \%$ to a $70 \%$ of CP target recommended by Broderick (1995) for improving the protein-use efficiency and milk production by dairy cattle. Recently published lactation trials with BFT silages support the premise that modest levels of CT can improve protein-use efficiency and milk production (Hymes-Fecht et al., 2013). Concentrations of $\mathrm{CT}$ needed to reach the $70 \%$ of $\mathrm{CP}$ target for RDP would presumably be greater in less-mature, high-protein forages, whereas less CT may be needed in more-mature, lower-protein forages. Natural or bioengineered forages producing $\mathrm{CT}$ with a chemistry differing from that expressed in BFT forages also might require somewhat different amounts of $\mathrm{CT}$ to reach the established target for RDP.

\section{CONCLUSIONS}

Our in situ evaluations of ruminal protein disappearance from alfalfa and BFT forages indicated that discrete lag time and fraction B increased linearly in a positive relationship with concentrations of $\mathrm{CT}$ that ranged from 0 to $2.77 \%$ of DM. Conversely, estimates for fraction $\mathrm{A}, \mathrm{K}_{\mathrm{d}}$, and RDP decreased linearly with $\mathrm{CT}$, and most of these linear regressions exhibited relatively high coefficients of determination. Although no true standard methodology exists for estimating RDP, the significant positive relationship of lag time with CT content strongly suggests the LADJ method would be most sensitive for estimating the effects of $\mathrm{CT}$ on estimates of RDP whenever CT-containing hays and silages are evaluated by in situ methods. If both $\mathrm{RDP}_{\mathrm{LADJ}}$ and $\mathrm{CT}$ are expressed on a percentage of $\mathrm{CP}$ basis, regression slopes indicated each unit of CT protected 0.61 units of CP in hay and silage from ruminal degradation. Applying this relationship to a typical forage legume containing $21 \% \mathrm{CP}$ suggests that a CT concentration of $3.8 \%$ of $\mathrm{DM}$ would be needed to reduce the RDP of hay or silage from $81 \%$ of $\mathrm{CP}$ to a $70 \%$ target proposed as optimal for improving protein utilization and milk production by dairy cattle.

\section{ACKNOWLEDGMENTS}

The authors thank Lee Massingill and Christy Davidson (both of the USDA-ARS, US Dairy Forage Research 
Center, Madison, WI), Robin Ogden (USDA-ARS, US Dairy Forage Research Center, Marshfield, WI), and Mary Becker (USDA-ARS, US Dairy Forage Research Center, Madison, WI) for excellent technical assistance with sample preparation, as well as in situ and laboratory analyses. Seed of BFT and alfalfa generously were provided by Heathcliffe Riday (USDA-ARS, US Dairy Forage Research Center, Madison, WI), DLFTrifolium (Roskilde, Denmark), Cropmark Seeds Ltd. (Christchurch, New Zealand), the Margot Forde Forage Germplasm Centre (Palmerston North, New Zealand), Deer Creek Seed Inc. (Ashland, WI), and ABI Alfalfa Inc. (Ames, IA).

\section{REFERENCES}

Aerts, R. J., W. C. McNabb, A. Molan, A. Brand, T. N. Barry, and J. S. Peters. 1999. Condensed tannins from Lotus corniculatus and Lotus pedunculatus exert different effects on the in vitro rumen degradation of ribulose-1,5-bisphosphate carboxylase/oxygenase (Rubisco) protein. J. Sci. Food Agric. 79:79-85.

AOAC International. 1998. Official Methods of Analysis. 16th ed., 4th rev. Method No. 990.03. AOAC International, Gaithersburg, MD.

Broderick, G. A. 1994. Quantifying forage protein quality. Pages 200228 in Forage Quality, Evaluation, and Utilization. G. C. Fahey Jr., M. Collins, D. R. Mertens, and L. E. Moser, ed. American Society of Agronomy-Crop Science Society of America-Soil Science Society of America (ASA-CSSA-SSSA), Madison, WI.

Broderick, G. A. 1995. Desirable characteristics of forage legumes for improving protein utilization in ruminants. J. Anim. Sci $73: 2760-2773$

Broderick, G. A., and K. A. Albrecht. 1997. Ruminal in vitro degradation of protein in tannin-free and tannin-containing forage legume species. Crop Sci. 37:1884-1891.

Buxton, D. R., J. S. Hornstein, W. F. Wedin and G. C. Marten. 1985. Forage quality in stratified canopies of alfalfa, birdsfoot trefoil, and red clover. Crop Sci. 25:273-279.

Cassida, K. A., T. S. Griffin, J. Rodriguez, S. C. Patching, O. B. Hesterman, and S. R. Rust. 2000. Protein degradability and forage quality in maturing alfalfa, red clover, and birdsfoot trefoil. Crop Sci. 40:209-215.

Coblentz, W. K., G. E. Brink, N. P. Martin, and D. J. Undersander. 2008. Effects of harvest timing on estimates of rumen degradable protein from alfalfa forages. Crop Sci. 48:778-788.

Coblentz, W. K., J. O. Fritz, R. C. Cochran, W. L. Rooney, and K. K. Bolsen. 1997. Protein degradation responses to spontaneous heating in alfalfa hay evaluated by in situ and ficin methods. J. Dairy Sci. 80:700-713.

Coblentz, W. K., J. O. Fritz, W. H. Fick, R. C. Cochran, and J. E. Shirley. 1998. In situ dry matter, nitrogen, and fiber degradation of alfalfa, red clover, and eastern gamagrass at four maturities. J. Dairy Sci. 81:150-161.

Coblentz, W. K., P. C. Hoffman, and N. P. Martin. 2010. Effects of spontaneous heating on forage protein fractions and in situ disappearance kinetics of crude protein for alfalfa-orchardgrass hays packaged in large-round bales. J. Dairy Sci. 93:1148-1169.

Grabber, J. H. 2009. Protein fractions in forage legumes containing protein-binding polyphenols: Freeze-drying vs. conservation as hay or silage. Anim. Feed Sci. Technol. 151:324-329.

Grabber, J. H., and W. K. Coblentz. 2009. Polyphenol, conditioning, and conservation effects on protein fractions and degradability in forage legumes. Crop Sci. 49:1511-1522.

Grabber, J. H., W. K. Coblentz, and G. A. Broderick. 2011. Rumendegradable protein in roll-conditioned or macerated legume hays and silages estimated by in situ kinetics vs. alternative methods. Crop Sci. 51:1832-1839.
Hancock, K. R., V. Collette, K. Fraser, M. Greig, H. Xue, K. Richardson, C. Jones, and S. Rasmussen. 2012. Expression of the R2R3MYB transcription factor TaMYB14 from Trifolium arvense activates proanthocyanidin biosynthesis in the legumes Trifolium repens and Medicago sativa. Plant Physiol. 159:1204-1220.

Hoffman, P. C., S. J. Sievert, R. D. Shaver, D. A. Welch, and D. K. Combs. 1993. In situ dry matter, protein, and fiber degradation of perennial forages. J. Dairy Sci. 76:2632-2643.

Hristov, A. N., and S. G. Sandev. 1998. Proteolysis and rumen degradability of protein in alfalfa preserved as silage, wilted silage or hay Anim. Feed Sci. Technol. 72:175-181.

Hymes-Fecht, U. C., G. A. Broderick, R. E. Muck, and J. H. Grabber. 2013. Replacing alfalfa or red clover silage with birdsfoot trefoil silage in total mixed rations increases production of lactating dairy cows. J. Dairy Sci. 96:460-469.

Makkar, H. P. S., G. Gamble, and K. Becker. 1999. Limitation of the butanol-hydrochloric acid-iron assay for bound condensed tannins. Food Chem. 66:129-133.

Makoni, N. F., G. A. Broderick, and R. E. Muck. 1997. Effect of modified atmospheres on proteolysis and fermentation of ensiled alfalfa. J. Dairy Sci. 80:912-920.

McAllister, T. A., T. Martinez, H. D. Bae, A. D. Muir, L. J. Yanke, and G. A. Jones. 2005. Characterization of condensed tannins purified from legume forages: Chromophore production, protein precipitation, and inhibitory effects on cellulose digestion. J. Chem. Ecol. 31:2049-2068.

McDonald, I. 1981. Short note: A revised model for the estimation of protein degradability in the rumen. J. Agric. Sci. 96:251-252.

Mertens, D. R., and J. R. Loften. 1980. The effect of starch on forage fiber digestion kinetics in vitro. J. Dairy Sci. 63:1437-1446.

Minnee, E. M. K., S. L. Woodward, G. C. Waghorn, and P. G. Laboyrie. 2002/2003. The effect of ensiling forage legumes on condensed tannins. Agronomy-New Zealand 32-33:117-119.

Nagel, S. A., and G. A. Broderick. 1992. Effect of formic acid or formaldehyde treatment of alfalfa silage on nutrient utilization by dairy cows. J. Dairy Sci. 75:140-154.

NRC. 2001. Nutrient Requirements of Dairy Cattle. 7th rev. ed. National Academy Press, Washington, DC

Ogden, R. K., W. K. Coblentz, K. P. Coffey, J. E. Turner, D. A. Scarbrough, J. A. Jennings, and M. D. Richardson. 2006. In situ disappearance kinetics of nitrogen and neutral detergent insoluble nitrogen for common crabgrass sampled on seven dates in northern Arkansas. J. Anim. Sci. 84:669-677.

Ørskov, E. R., and I. McDonald. 1979. The estimation of protein degradability in the rumen from incubation measurements weighted according to rate of passage. J. Agric. Sci. (Camb.) 92:499-503.

Owens, V. N., K. A. Albrecht, R. E. Muck, and S. H. Duke. 1999. Protein degradation and fermentation characteristics of red clover and alfalfa silage harvested with varying levels of total nonstructural carbohydrates. Crop Sci. 39:1873-1880.

Patra, A. K., and J. Saxena. 2011. Exploitation of dietary tannins to improve rumen metabolism and ruminant nutrition. J. Sci. Food Agric. 91:24-37.

Rioux, R., G. T. Dos Santos, H. V. Petit, and J. G. Proulx. 1995. Effects of cultivars on in vitro and ruminal degradation of the nitrogen fraction in birdsfoot trefoil silage. J. Dairy Sci. 78:1766-1773.

SAS Institute. 2002. SAS User's Guide: Statistics. Version 9.2. SAS Inst. Inc., Cary, NC.

Schofield, P., D. M. Mbugua, and A. N. Pell. 2001. Analysis of condensed tannins: A review. Anim. Feed Sci. Technol. 91:21-40.

Sivakumaran, S., W. Rumball, G. A. Lane, K. Fraser, L. Y. Foo, M. $\mathrm{Yu}$, and L. P. Meagher. 2006. Variation of proanthocyanidins in Lotus species. J. Chem. Ecol. 32:1797-1816.

Terrill, T. H., W. R. Windham, J. J. Evans, and C. S. Hoveland. 1990 Condensed tannin concentration in Sericea lespedeza as influenced by preservation method. Crop Sci. 30:219-224.

Vanzant, E. S., R. C. Cochran, and E. C. Titgemeyer. 1998. Standardization of in situ techniques for ruminant feedstuff evaluation. J. Anim. Sci. 76:2717-2729

Vanzant, E. S., R. C. Cochran, E. C. Titgemeyer, S. D. Stafford, K. C. Olsen, D. E. Johnson, and G. St. Jean. 1996. In vivo and in situ 
measurements of forage protein degradation in cattle. J. Anim. Sci. 74:2773-2784.

Verdier, J., J. Zhao, I. Torres-Jerez, S. Ge, C. Liu, X. He, K. S. Mysore, R. A. Dixon, and M. K. Udvardi. 2012. MtPAR MYB transcription factor acts as an on switch for proanthocyanidin biosynthesis in Medicago truncatula. Proc. Natl. Acad. Sci. USA 109:1766-1771.

Waghorn, G. C. 2008. Beneficial and detrimental effects of dietary condensed tannins for sustainable sheep and goat productionProgress and challenges. Anim. Feed Sci. Technol. 147:116-139.
Waghorn, G. C., M. J. Ulyatt, A. John, and L. J. Fisher. 1987. The effect of condensed tannins on the site of digestion of amino acids and other nutrients in sheep fed on Lotus corniculatus. Br. J. Nutr. 57:115-126.

Zinn, R. A., and F. N. Owens. 1986. A rapid procedure for purine measurement and its use for estimating net ruminal protein synthesis. Can. J. Anim. Sci. 66:157-166. 